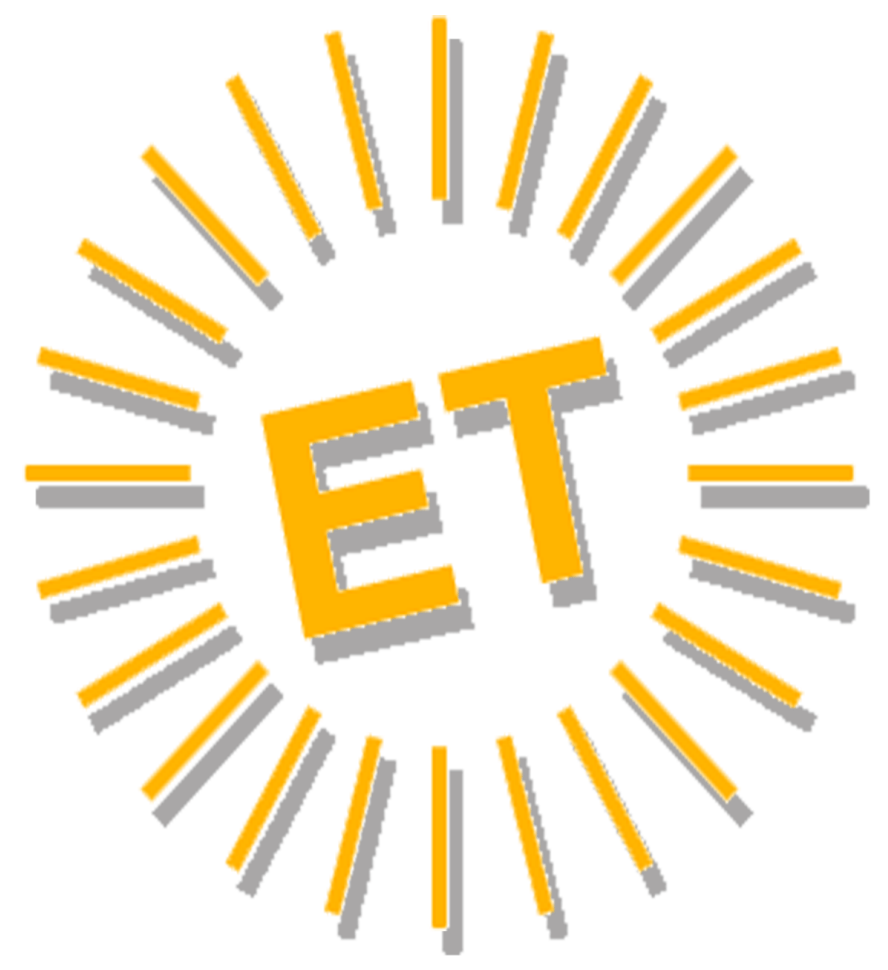




\section{Editorial Team}

\section{Editor in Chief}

Alfonso Vargas-Sánchez, University of Huelva, Spain

\section{Associate Editor}

Mirko Perano, Reald University College, Albania

\section{Books Review Editor}

Brendan Paddison, York St. John University, United Kingdom

\section{Secretariat}

Elena García de Soto, University of Huelva, Spain

Cinta Borrero-Domínguez, University of Seville, Spain

\section{Style reviewer and text editor}

Anestis Fotiadis, Zayed University, United Arab Emirates

\section{Editorial Board}

José Manuel Alcaraz, Murdoch University, Australia Mario Castellanos-Verdugo, University of Seville, Spain José Antonio Fraiz-Brea, University of Vigo, Spain José Manuel Hernández-Mogollón, University of Extremadura, Spain

Tzung-Chen Huan, National Chiayi University, Taiwan, Province of China

Shaul Krakover, Ben Gurion University, Israel Jean Pierre Levy-Mangin, University of Quebec, Canada Tomás López-Guzmán, University of Córdoba, Spain Yasuo Ohe, Chiba University, Japón

María de los Ángeles Plaza-Mejía, University of Huelva, Spain Nuria Porras-Bueno, University of Huelva, Spain João Albino Silva, Algarve University, Portugal

\section{Advisory Board (Spanish Members)}

Juan Manuel Berbel-Pineda, Pablo de Olavide University, Spain César Camisón-Zornoza, Uniersity of Valencia, Spain Enrique Claver-Cortés, University of Alicante, Spain María Teresa Fernández-Alles, University of Cádiz, Spain José Luis Galán-González, University of Seville, Spain Félix Grande-Torraleja, University of Jaén, Spain

Antonio Leal-Millán, University of Seville, Spain Inmaculada Martín-Rojo, University of Málaga, Spain Antonio Manuel Martínez-López, University of Huelva, Spain Francisco José Martínez-López, University of Huelva, Spain Pablo A. Muñoz-Gallego, University of Salamanca, Spain
Francisco Riquel-Ligero, University of Huelva, Spain José Miguel Rodríguez-Antón, Autonomous University of Madrid, Spain

Sandra Sanchez-Cañizares, University of Cordoba, Spain Josep Francesc Valls-Giménez, ESADE, Spain

\section{Advisory Board (Other European Members)}

Tindara Abbate, University of Messina, Italy Paulo Aguas, University of Algarve, Portugal Carlos Costa, Aveiro University, Portugal Dianne Dredge, Aalborg University, Denmark Salvatore Esposito de Falco, University of Rome "La Sapienza", Italy

Sheila Flanagan, Dublín Institute of Technology, Ireland Tania Gorcheva, Tsenov Academy of Economics, Bulgaria Tadeja Jere Jakulin, University of Primorska, Slovenia Metin Kozak, Mugla University, Turkey Álvaro Matias, Lusiada University, Portugal Alfonso Morvillo, National Research Council, Italy Alexandru Nedelea, Stefan cel Mare University of Suceava, Romania Claudio Nigro, University of Foggia, Italy Angelo Presenza, University "G. D'Annunzio" of Chieti-Pescara, Italy

Kanes Rajah, Royal Agricultural University, United Kingdom

\section{Advisory Board (Members from the rest of the world)}

John Allee, American University of Sharjah, United Arab Emirates

Nestor Pedro Braidot, National University of La Plata, Argentina

Roberto Elias Canese, Columbia University, Rector, Paraguay

Luca Casali, Queensland University of Technology, Australia Nimit Chowdhary, Indian Institute of Tourism and Travel Management, India

Steven Chung-chi Wu, National Pingtung University of Science and Technology, Taiwán

Dianne Dredge, Southern Cross University, Australia Daniel Fesenmaier, Temple University, United States

Babu George, Alaska Pacific University, United States Dogan Gursoy, Washington State University, United States Jafar Jafari, University of Wisconsin-Stout, United States Sanggun Lee, Pai Chai University, Korea Republic of Albert Yeh Shangpao, I-SHOU University, Taiwán Pauline Sheldon, University of Hawaii, United States Germán A. Sierra-Anaya, University of Cartagena de Indias, Rector, Colombia Xiaohua Yang, University of San Francisco, United States 


\title{
ASTROTOURISM: A LITERATURE REVIEW AND FRAMEWORK FOR FUTURE RESEARCH
}

\author{
AlbertoTapada \\ University of Trás-os-Montes and Alto Douro (Portugal) \\ alberto tapada@yahoo.com
}

Carla S. Marques

University of Trás-os-Montes and Alto Douro (Portugal)

smarques@utad.pt

Carlos P. Marques

University of Trás-os-Montes and Alto Douro (Portugal)

cmarques@utad.pt

Carlos Costa

University of Aveiro (Portugal)

ccosta@ua.pt

\begin{abstract}
Astrotourism consists of activities focused on observing night skies and celestial phenomena in natural spaces, which contributes to communities' involvement, empowerment and participation and to regional development. In addition to documenting the increased academic research on astrotourism, this literature review sought to construct a general theoretical framework for this field by analysing scholars' contributions and highlighting the ways in which this topic has been viewed over time. The analyses were based on the academic publications on astrotourism indexed in the Scopus
\end{abstract}


and Web of Science databases up to 2019. A total of 61 documents were subjected to a selection process and eligibility analysis until the sample was reduced to a final set of 42 articles. Qualitative methods were applied to cluster the articles into three themes and analyse each document. This study appears to be the first literature review focused on astrotourism. The results highlight the most researched themes over the years, investigations' characteristics and gaps in the literature that open doors for future empirical research. The main issues already addressed by the academic community are related to the problems of light pollution, sustainability and regional development, among others, but much room remains for other studies.

KEYWORDS

Astrotourism; Sustainable Development; Starlight Tourism Destination; Local Community; Literature Review.

ECONLITE KEYS

ZOO; Z32; Z39

\section{INTRODUCTION}

Astronomical tourism is a multifaceted, multidimensional phenomenon situated at the crossroads of various types of interactions within societies (Charlier \& Bourgeois, 2013). This niche tourism can be a valuable resource for low-density areas (Rodrigues, Rodrigues, \& Peroff, 2015; Jacobs, Du Preez, \& Fairer-Wessels, 2019; Soleimani, Bruwer, Gross, \& Lee, 2019), but the focus on astrotourism is only a recent one - part of a growing consumerist tendency to see the night sky as a resource that is rare, valuable and debated. Astrotourism fosters new experiences and undiluted contact with protected, natural spaces (Fayos-Solá, Marín, \& Jafari, 2014; Matos, 2017; Cooper et al., 2018).

The increasing demand for the night sky is due to the combined efforts of astronomers, academics, ecologists and associated movements to defend starry skies. These efforts have led to the creation of dark-sky reserves and starlight parks worldwide, which consist of spaces generally linked to intact natural areas with low air pollution values and far from light pollution sources. Thus, astrotourism has become an important way to promote, use and defend night skies because of consumers' growing awareness of this resource (Iwaniszewski, 2015; Cooper et al., 2018).

The present study sought to conduct a literature review in order to evaluate all the research on astrotourism and boost investigations in this field by tracing a general outline of the topic and identifying the academic contributions published until 2019. A survey of the existing studies is crucial to identifying this field's origin and 
understanding how these activities are viewed by the academic community. In addition, literature reviews facilitate the identification of which issues have received more attention from researchers, areas less often researched and topics that can and should be studied in the future. This survey thus contributes to the astrotourism field's development and recognition and answers the following main research questions:

Q1: What are the most studied subjects in previous research on astrotourism?

Q2: What are the characteristics of previous astrotourism studies including (1) number of publications per year, (2) types of documents, (3) most cited articles, (4) authors with most publications, (5) countries and/or continents with most publications and (6) most frequently used research methodologies?

Q3: What gaps exist in astrotourism research that future studies can address?

Given the proposed research questions, this paper contains, first, a brief literature review based on the conceptualisation of astrotourism and the problem of light pollution - two of the main topics associated with astronomical tourism. The review is followed by a presentation of the methodology and results. The paper then answers the research questions, discusses the findings, suggests future research and provides conclusions.

\section{PRESENT VIEWS ON ASTROTOURISM}

The magic and fear associated with solar and lunar movements, as well as other cosmic phenomena, have accompanied humanity throughout time, influencing and shaping the development of societies' thought patterns (Nilsson, 1920; Atkinson, 2007; Iwaniszewski, 2015). Ibrahim, Safiai and Jamsari (2015) define astrotourism as a set of tourism activities using equipment, while Korlević and Krajnović (1999) see this niche as a selective form of tourism focused on the night sky's attributes. Astrotourism converges on a growing demand for natural resources valued by consumerist societies that has made these assets gradually rarer and thus more valuable (Iwaniszewski, 2015).

Other researchers, such as Fayos-Solá et al. (2014), offer a more integrative definition, describing astrotourism as travellers' activities that seek to use the natural resource of night landscapes for leisure purposes. These activities are related to astronomy, knowledge and human capital, encompassing visitors and host 
communities and favouring a holistic appreciation of astronomical and archaeoastronomical heritage. More recently, Soleimani et al.'s (2019) definition has contributed to astrotourism's theoretical framework by positioning it as a special interest tourism (SIT) that is personalised. The cited authors also categorise astrotourism as a niche that favours sensory and cognitive experiences and that, concurrently, can be considered scientific, nature and cultural tourism (Charlier \& Bourgeois, 2013).

This effort to define a more stable conceptualisation of astrotourism has accompanied the growing movement to defend the night sky against light pollution's disquieting impacts, which is increasing at an average of $6 \%$ per year. An entire generation of individuals has been unable to contemplate the sky's magnitude in dark places (Wainscoat, 2009). Humanity is thus witnessing the loss of this part of its heritage, which is shrinking even in sanctuaries, parks and nature reserves (Begley, 2016; Cooper et al., 2018; Mitchell \& Gallaway, 2019; Priyatikanto et al., 2019; Wei, Chen, Xiu, Yu, \& Liu, 2019).

Observatories have traditionally been established far from urban centres, gradually moving to ever more distant natural areas, as was the case with the Vatican Observatory (Challéat, 2011). Current trends pose a challenge to models applied to light requalification, protection of intact skies and pollution reduction (Challéat, 2011; Aube \& Roby, 2014; Papalambrou \& Doulos, 2019). These efforts seek to protect wildlife, ecosystems and the environment in general (Lima, Pinto da Cunha, \& Peixinho, 2016; Papalambrou \& Doulos, 2019; Wei et al., 2019), especially with regard to species' interactions (Longcore \& Rich, 2004; Nie, Lan, \& Yu, 2019) and the preservation of starry skies as an essential element of all cultures (Marín, Wainscoat, \& Fayos-Solá, 2010).

In 2009, the need to conserve tangible astronomical heritage was translated by the International Dark-Sky Association (IDA) and the United Nations Educational, Scientific, and Cultural Organisation (UNESCO) into the International Year of Astronomy. Other associations, such as the International Union for Conservation of Nature, have encouraged the gathering of knowledge about and the defence of starry skies and night-time environments' potential. New forms of protection have emerged along with the development of natural and cultural heritage in association with dark- 
sky and starlight parks and reserves, adding tourism value to this legacy (Charlier \& Bourgeois, 2013).

The Royal Astronomical Society of Canada, IDA and associated movements' objectives are centred around protecting starry skies. Experts have also defined frameworks and labels that focus on the relevant parks and reserves, which are currently attributed by the Starlight Foundation, which was established in 2007 with the support of UNESCO and the International Astronomical Union (IAU). All these organisations have converged on the fight against pollution and efforts to preserve valuable sites (Ruggles \& Clotte, 2010).

This alignment and the labels promoted by these organisations and formulated by the World Tourism Organisation (WTO) have naturally highlighted these resources' connection to tourism as substantive regional assets (Gumuchian \& Pecqueur, 2007). The current trends have generated a new supply in response to a clear demand, namely, astronomical tourism framed as authentic identity and shaped by strict classifications and institutionalised intermediaries (Landel, 2007).

In addition, UNESCO and the IAU launched the Astronomy and World Heritage programme, instructing the International Council on Monuments and Sites (ICOMOS) to integrate the relevant locations as World Heritage sites (Ruggles \& Clotte, 2010). The understanding between UNESCO and the Starlight Foundation has resulted in the greater recognition of the heavens as an invaluable human and natural source. Thus, astronomical heritage has been strengthened, and tourists support the preservation of scientific, cultural and environmental values (Charlier \& Bourgeois, 2013; Jacobs et al., 2019).

This organisational trajectory has further propelled astrotourism offers' transformation into an increasingly valued commodity because it is different, scarce and precious (Iwaniszewski, 2015). Astrotourism has gained a rich set of classifications, protection measures and light pollution reversal processes, and these activities have been assessed as having outstanding universal value for humanity. This increasing prominence has received extensive support from the Declaration in Defence of the Night Sky and the Right to Starlight - adopted at La Palma in April 2007 - and by the elevation of this island's Starlight Reserve to a World Heritage site (Marín \& Orlando, 2009). 
The above trends and societal scope of this recent multifaceted, multidimensional phenomenon (Charlier \& Bourgeois, 2013) has created a need to define astrotourism's conceptual geography to facilitate the certification of protected natural territories. The results could contribute to this concept's delineation, the associated resources' prominence and experiential or contemplative astrotourism's professionalisation (Begley, 2016; Jacos et al., 2019).

Astrotourism's various forms include observations of comets and eclipses, astrophotography, visits to public astronomical observatories, archaeotourism and ethno-tourism ${ }^{1}$. Astrotourism travellers also participate in celebrations or observations of solstices, equinoxes, aurora borealis and other events in the astronomical calendar, which motivate tourists' visits (Iwaniszewski, 2015). These activities highlight the source of humanity's inspiration to embark on scientific and technological discoveries (Soleimani et al., 2019), thereby encouraging starry skies' preservation and protection (Marín \& Jafari, 2007).

\section{METHODOLOGY}

Astrotourism is an only recently researched topic, so an evaluation is needed of the studies already carried out in this field to gain insights that will help define objectives for future investigations (Ibrahim, Ahmad, Safiai, \& Mujani, 2012; Ibrahim et al., 2015; Moher et al., 2015; Snyder, 2019). The present research thus applied one of the most frequently used qualitative methods in the social sciences - literature reviews - in order to systematise all existing information on the topic under study and contribute substantively to increasing the existing knowledge.

\section{1) CHARACTERISATION OF SEARCH CRITERIA}

The preferred reporting items for systematic reviews and meta-analyses (PRISMA) methodology guidelines (Moher, Liberati, Tetzlaff, \& Altman, 2009) suggest that a

\footnotetext{
1 According to Atkinson (2007) and Iwaniszewski (2015), archaeotourism and ethno-tourism are a form of astrotourism, since the former learns from the past remains (e.g., archaeological artifacts and human remains) about how different groups and societies perceived and used the skies and the latter studies and recognises celestial bodies as part of living traditions (e.g., mythology, worship, architectural alignment of monuments) with important emotional and cultural significance.
} 
literature review must comprise four distinct phases: identification, selection, eligibility and inclusion. In the first phase, the search criteria are defined for a chosen database, while, in the next phase, the results are selected that best fit the established search criteria. All the relevant articles are then classified based on their characteristics, and, in the final phase, the set of documents that fit within the research topic under study are included in the final sample.

\subsection{1) PHASE 1: IDENTIFICATION}

To identify the articles reporting astrotourism studies, a search was performed using Clarivate Analytics' main indexed database, Web of Science (WoS), which contains publications since the beginning of the twentieth century and which is constantly updated. WoS is one of the largest, most important databases of academic journals, containing a set of associated indexes. To obtain as many documents as possible, a search was also conducted using Elsevier's Scopus, the largest bibliographic database, which is available only to subscribers. Scopus contains 1.4 billion references cited since 1970, as well as 70 million documents and 16 million author profiles.

Through a primary literature review and reading on astrotourism, several keywords associated with the study of this theme were identified and, in many cases, synonymous terms. In order to find the maximum number of publications in this area, the following keywords were used to start the research process in both databases (see Figure 1):

- Astronomical ecotourism camps

- Astronomical outreach

- Astronomical tourism

- Astrotourism

- Astro-tourism

- Astrotourist

- Astro-tourist

- Aurora borealis tourism

- Aurora tourists

- Celestial ecotourism

- Dark skies tourism 
- Dark sky park

- Dark sky parks

- Dark sky programme

- Dark sky reserve

- Dark sky reserves

- Darkness of night skies

- Dark-sky preserves

- Dark-sky site

- Night skies

- Night station observatories

- Northern lights tourism

- Space tourism

- Tall ship astronomy cruises

- Terrestrial space tourism

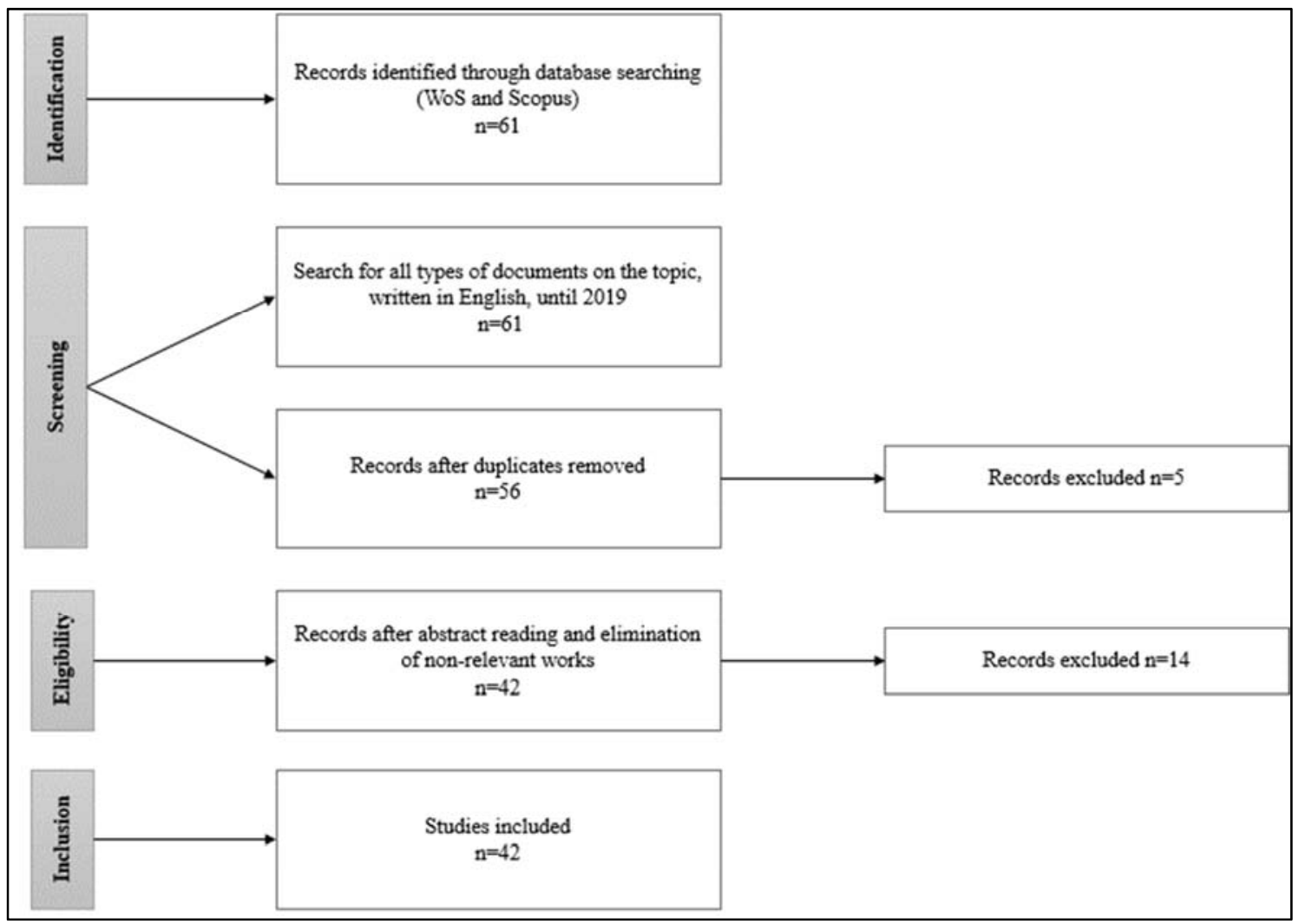

Figure 1. Characterisation of research based on PRISMA methodology Source: Adapted from Moher et al. (2009)

\subsection{2) PHASE 2: SELECTION}


Although various criteria were applied during the selection process, the search was carried out in the same way for both databases, without any filter regarding the time interval (i.e. until 2019), type of document or research area. English was selected as the only language, resulting in a set of 61 documents. However, the overall results from WoS and Scopus included a duplication of five records, which were eliminated from WoS, keeping the works indexed in Scopus. After this process, a total of 56 documents were obtained from the search (see Figure 1 above).

\subsection{3) PHASES 3 AND 4: ELIGIBILITY AND INCLUSION}

After the above refinement, the documents' abstracts were read to assess their relevance to the present review. This process resulted in the conclusion that most of the articles, proceedings papers, conference papers, critical reviews, news and book chapters fit into the subject matter under study. However, 14 documents were not related to astrotourism within the scope defined for the present research because their focus was on photography, technology, computer programmes, software, optics and arts and literature, among other subjects. These documents were disregarded as they would not contribute significantly to the subsequent analyses. Therefore, after checking each document's eligibility, the sample contained 42 documents whose contributions offered added value to this review (see Figure 1 above).

After the inclusion phase, each document's contents were examined in detail using structural analysis. The latter considered bibliometric factors such as the number of citations, country of publication and area of research. This information was registered on a Microsoft Excel worksheet.

\section{ANALYSIS OF RESULTS}

\section{1) BRIEF DESCRIPTION OF SAMPLE}

The two databases (i.e. WoS and Scopus) facilitated the construction of a graph showing the number of articles published per year (see Figure 2). These results highlight the embryonic nature of academic research in this field, as well as revealing 
a trend towards increased publications. An analysis of the graph confirmed that the first academic study of astrotourism dates from 1998. Only 4 more articles were published (i.e. in 2000, 2006, 2010 and 2011) in this area until 2012, which alone accounted for 4 publications. This year marked a change in the paradigm of astrotourism research as, from this date on, scholars showed an increased interest in this topic, with 2015 registering 6 works published. The data highlight that 2019 included the maximum number of publications ever in this field: 10 articles.

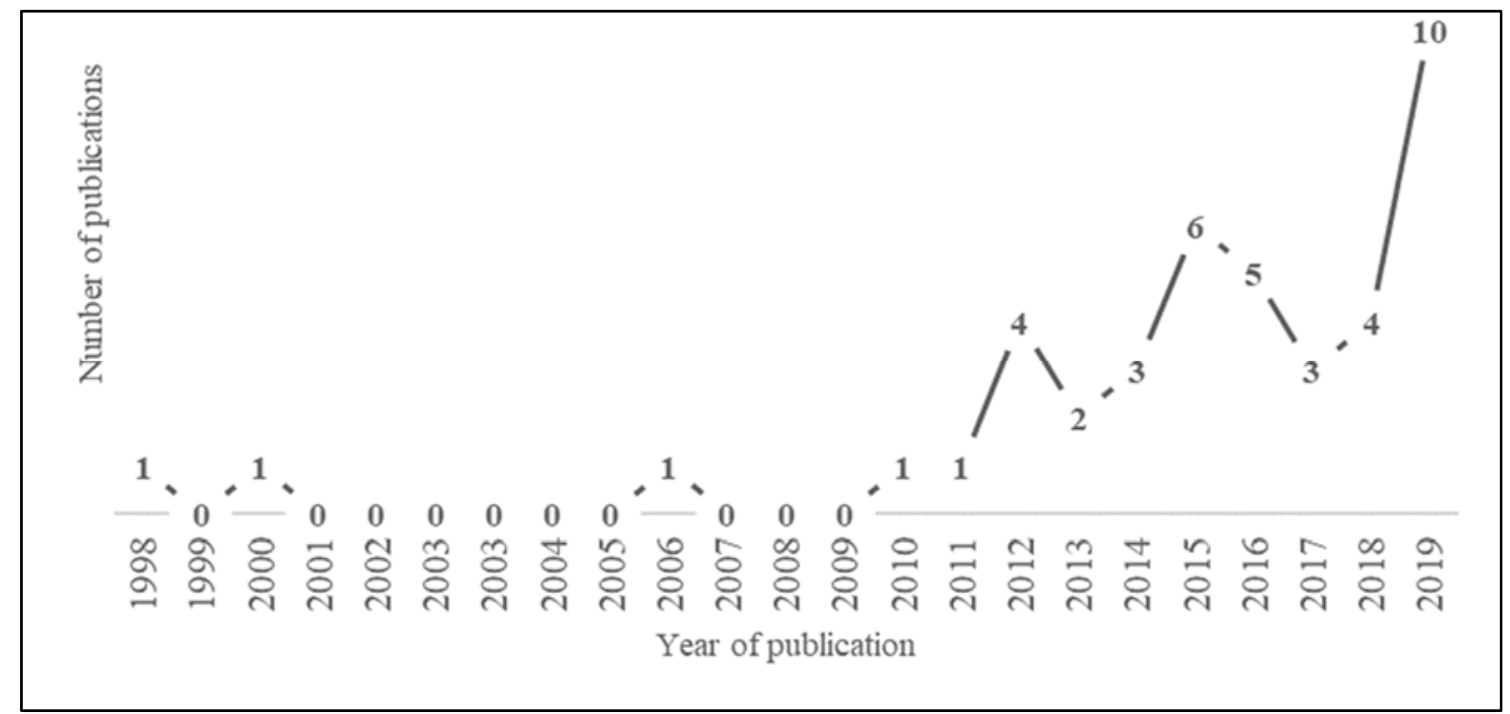

Figure 2. Number of publications per year (1998-2019) Source: Authors

Regarding the type of documents analysed, a percentage chart (see Figure 3) was prepared to define the typology of the 42 academic documents obtained from the aforementioned databases. Since no selection filter was applied to the results obtained, a wide diversity of publications was verified, with most being academic articles (57\%), followed by conference papers (22\%). Finally, smaller quantities were found of book chapters (7\%), critical book reviews $(7 \%)$ and news $(7 \%)$. 


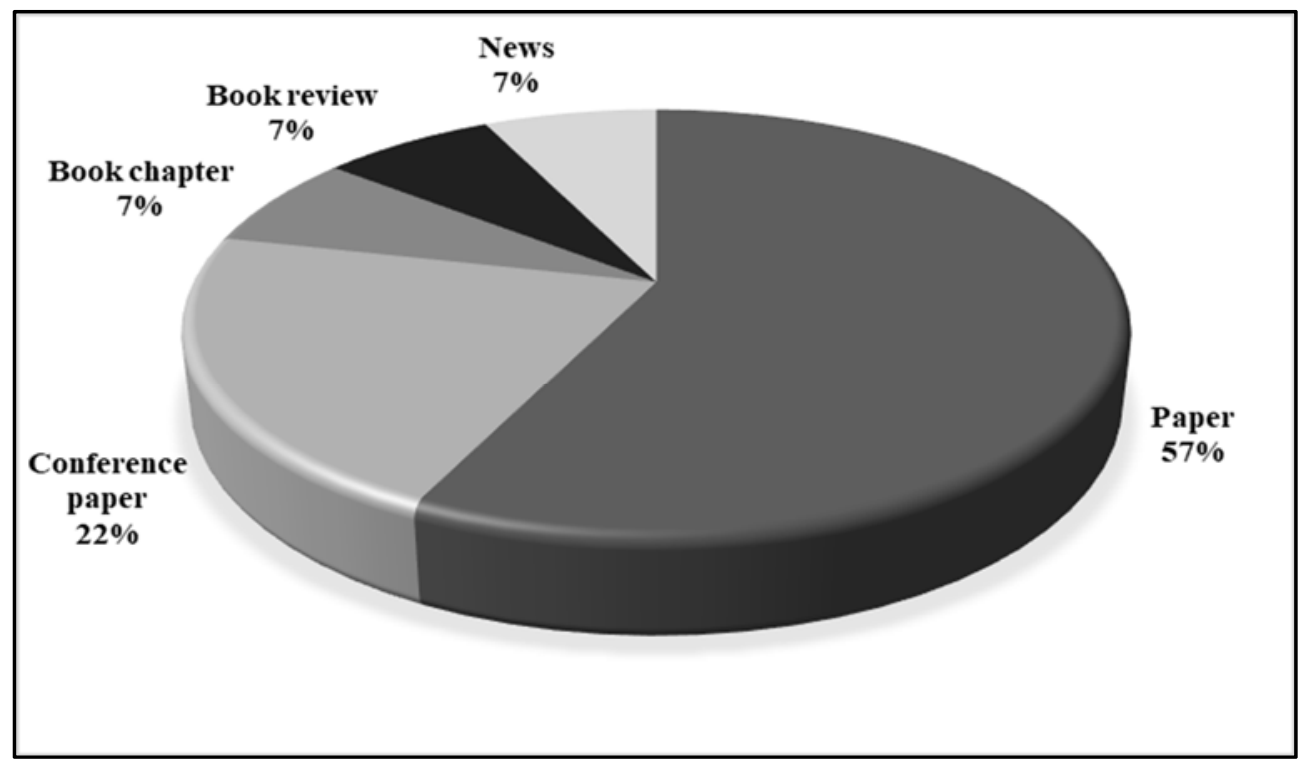

Figure 3. Types of documents published Source: Authors

Table 1 below presents an analysis of the top 10 articles with more than 5 citations in the databases consulted (i.e. Scopus and WoS). The two most cited works account for 22 citations each. These articles were published in 2013 and 2011 in Tourism Management Perspectives and Journal of Ecotourism, respectively, and both are indexed in Scopus.

\begin{tabular}{|c|c|c|c|c|c|}
\hline $\begin{array}{l}\text { Number } \\
\text { of } \\
\text { Citations }\end{array}$ & Authors & Title & Year & Journal & Database \\
\hline 22 & $\begin{array}{l}\text { Collison and } \\
\text { Poe }\end{array}$ & $\begin{array}{l}\text { 'Astronomical Tourism': The } \\
\text { Astronomy and Dark Sky } \\
\text { Program at Bryce Canyon } \\
\text { National Park }\end{array}$ & 2013 & $\begin{array}{l}\text { Tourism } \\
\text { Management } \\
\text { Perspectives }\end{array}$ & Scopus \\
\hline 22 & Weaver & $\begin{array}{l}\text { Celestial Ecotourism: New } \\
\text { Horizons in Nature-Based } \\
\text { Tourism }\end{array}$ & 2011 & $\begin{array}{l}\text { Journal of } \\
\text { Ecotourism }\end{array}$ & Scopus \\
\hline 20 & Cater & $\begin{array}{l}\text { Steps to Space: Opportunities for } \\
\text { Astrotourism }\end{array}$ & 2010 & $\begin{array}{c}\text { Tourism } \\
\text { Management }\end{array}$ & Scopus \\
\hline 20 & $\begin{array}{l}\text { Rodrigues et } \\
\text { al. }\end{array}$ & $\begin{array}{l}\text { The Sky and Sustainable Tourism } \\
\text { Development: A Case Study of a } \\
\text { Dark Sky Reserve } \\
\text { Implementation in Alqueva }\end{array}$ & 2015 & $\begin{array}{l}\text { International } \\
\text { Journal of } \\
\text { Tourism } \\
\text { Research } \\
\end{array}$ & Scopus \\
\hline 13 & Ibrahim et al. & $\begin{array}{l}\text { Functions of Astrofiqh } \\
\text { Observatories in Malaysia in } \\
\text { Solving Astrofiqh Issues }\end{array}$ & 2015 & $\begin{array}{l}\text { Mediterranean } \\
\text { Journal of } \\
\text { Social } \\
\text { Sciences } \\
\end{array}$ & Scopus \\
\hline 12 & $\begin{array}{l}\text { Aube and } \\
\text { Roby }\end{array}$ & $\begin{array}{l}\text { Sky Brightness Levels before and } \\
\text { after the Creation of the First } \\
\text { International Dark Sky Reserve, } \\
\text { Mont-Megantic Observatory, } \\
\text { Quebec, Canada }\end{array}$ & 2014 & $\begin{array}{l}\text { Journal of } \\
\text { Quantitative } \\
\text { Spectroscopy } \\
\text { \& Radiative } \\
\text { Transfer } \\
\end{array}$ & Wos \\
\hline 9 & Ibrahim et al. & $\begin{array}{l}\text { Islamic Astronomy and the } \\
\text { Establishment of Al-Khawarizmi } \\
\text { Complex in Malaysia }\end{array}$ & 2012 & $\begin{array}{l}\text { Advances in } \\
\text { Natural and } \\
\text { Applied } \\
\text { Sciences } \\
\end{array}$ & Scopus \\
\hline
\end{tabular}




\begin{tabular}{|c|c|c|c|c|c|}
\hline $\begin{array}{l}\text { Number } \\
\text { of } \\
\text { Citations }\end{array}$ & Authors & Title & Year & Journal & Database \\
\hline 9 & $\begin{array}{l}\text { Jóhannesson } \\
\text { and Lund }\end{array}$ & $\begin{array}{l}\text { Aurora Borealis: Choreographies } \\
\text { of Darkness and Light }\end{array}$ & 2017 & $\begin{array}{l}\text { Annals of } \\
\text { Tourism } \\
\text { Research }\end{array}$ & Scopus \\
\hline 6 & $\begin{array}{l}\text { Soleimani et } \\
\text { al. }\end{array}$ & $\begin{array}{l}\text { Astro-tourism } \\
\text { Conceptualisation as Special- } \\
\text { Interest Tourism (SIT) Field: A } \\
\text { Phenomenological Approach }\end{array}$ & 2019 & $\begin{array}{l}\text { Current Issues } \\
\text { in Tourism }\end{array}$ & Scopus \\
\hline 5 & $\begin{array}{l}\text { Papalambrou } \\
\text { and Doulos }\end{array}$ & $\begin{array}{l}\text { Identifying, Examining, } \\
\text { and Planning Areas Protected } \\
\text { from Light Pollution. The Case } \\
\text { Study of Planning the First } \\
\text { National Dark Sky Park in Greece }\end{array}$ & 2019 & Sustainability & WoS \\
\hline 5 & $\begin{array}{l}\text { Mitchell and } \\
\text { Gallaway }\end{array}$ & $\begin{array}{l}\text { Dark Sky Tourism: } \\
\text { Economic Impacts on } \\
\text { the Colorado Plateau Economy, } \\
\text { USA }\end{array}$ & 2019 & $\begin{array}{l}\text { Tourism } \\
\text { Review }\end{array}$ & Scopus \\
\hline
\end{tabular}

Next comes two more documents with 20 citations each and an article with 13 citations, all indexed in Scopus. WoS contributes 2 publications - one with 12 citations and the other with only 5 . All the other publications in the sample of articles have less than 5 citations each, and 20 articles had never been cited in other documents.

Figure 4 presents the graph of authors who have more than one academic article published in the field of astrotourism. This figure shows which authors have done more research and produced more academic publications in this field, highlighting Labuda's contributions, with three documents. Hearnshaw, Ibrahim, Safiai and Rodrigues each have 2 publications, while the rest only have 1 document on this topic.

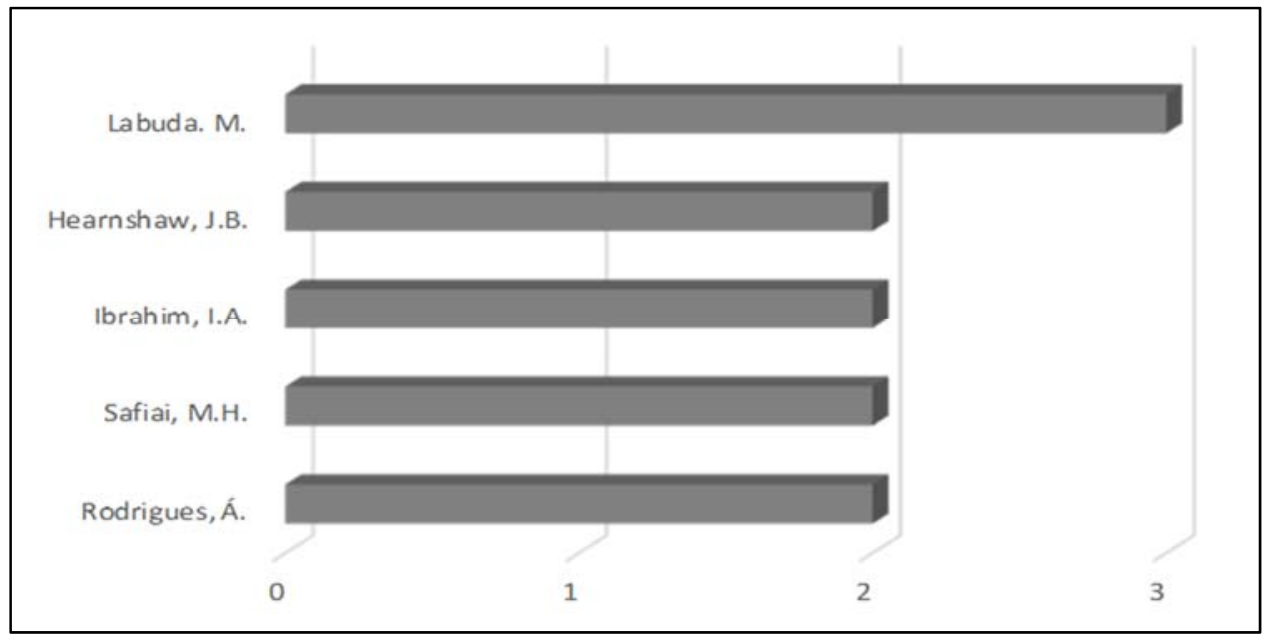

Figure 4. Authors with more than one published article on astrotourism Source: Authors 
Figure 5, in turn, presents a graph showing the countries that, from the selected papers, account for more than one published document on astrotourism. This figure reveals that the countries with the most academic publications on astrotourism are the United States (5) and United Kingdom (5), followed by Australia (3), Indonesia (3) and Portugal (3). Countries such as China, Slovakia, Spain, Malaysia, Mexico and New Zealand also have two documents each. All other countries with relevant publications that do not appear in this chart have only one document published in this field.

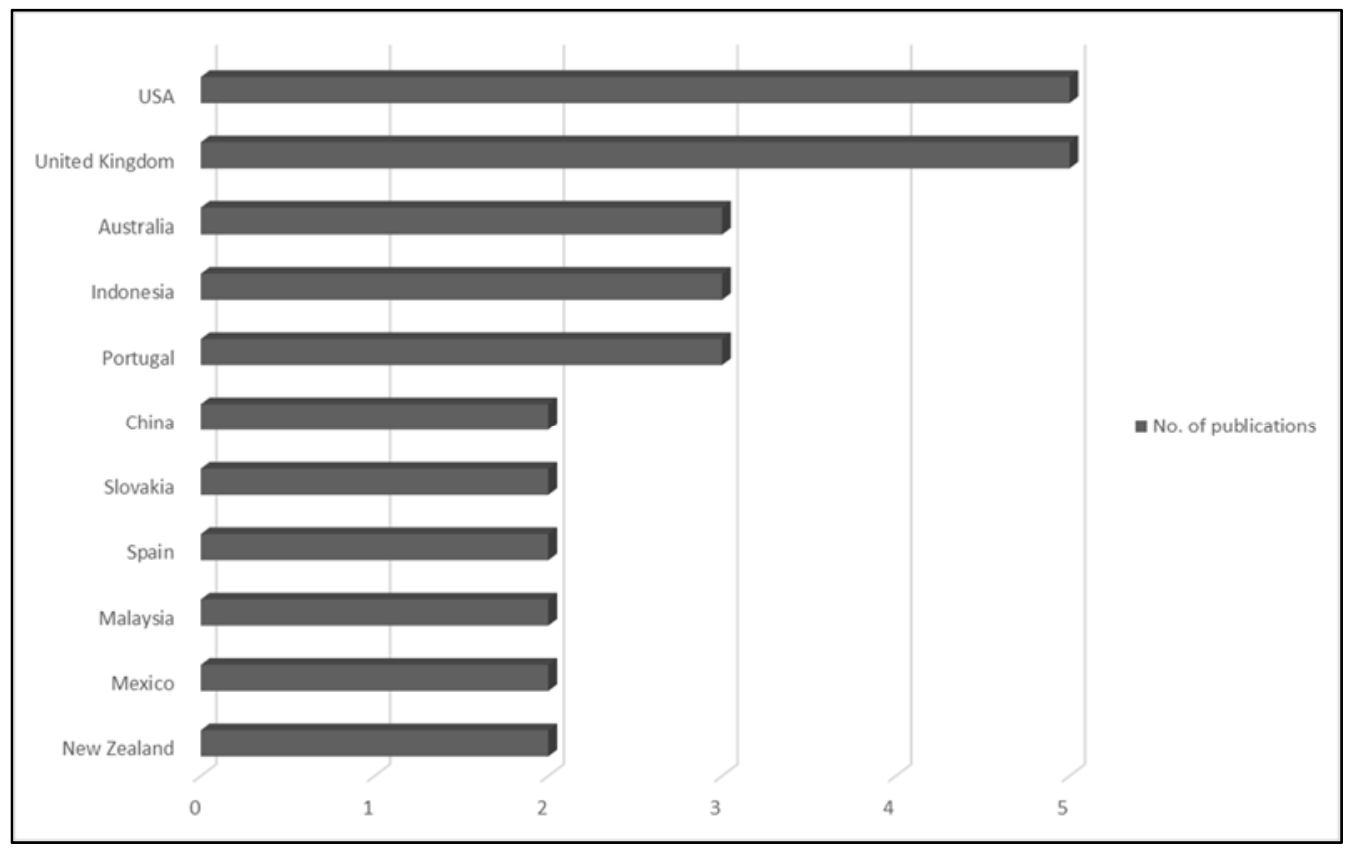

Figure 5. Countries with more than one publication on astrotourism Source: Authors

To complement these data, Figure 6 shows the continents that are associated with more than one astrotourism publication. A brief analysis of this figure confirmed that Europe leads with the highest count (17) and largest number of documents on astrotourism, followed by the Americas and Asia, both with 9 publications. Oceania has 5 , and, finally, the African continent is associated with only 2 documents. 


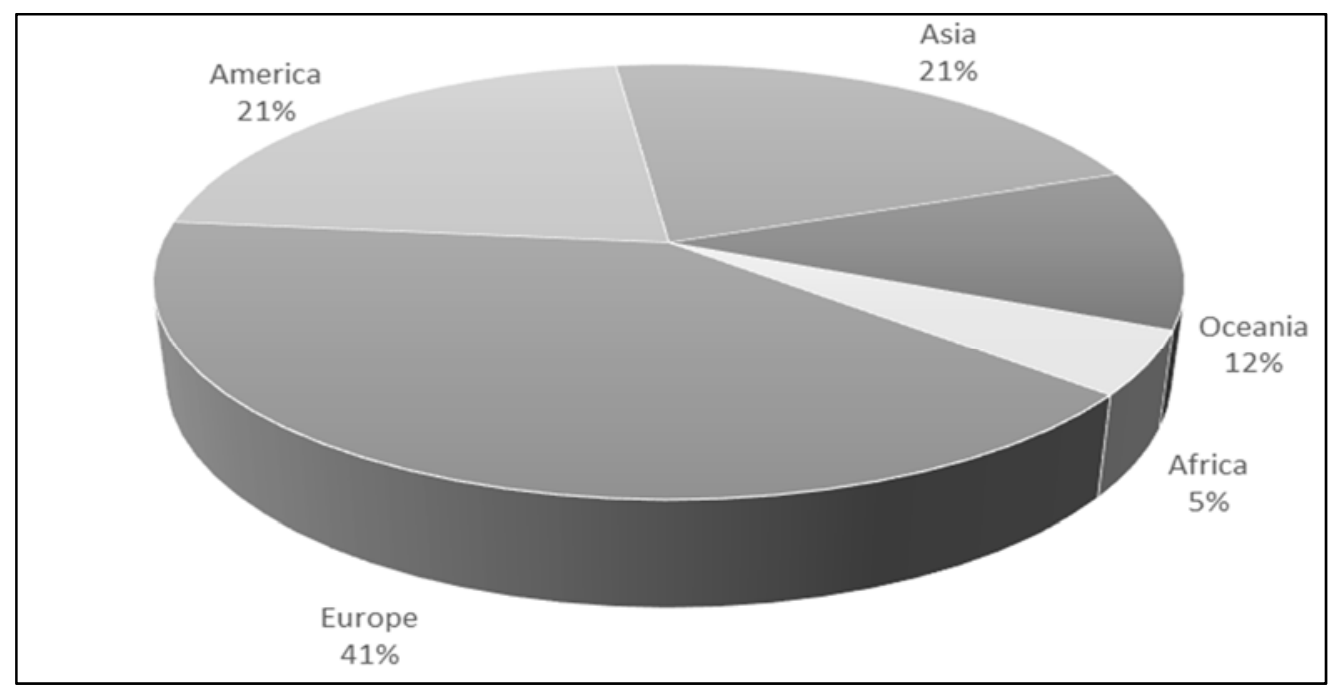

Figure 6. Number of articles per continent Source: Authors

The graph in Figure 7 depicts the methodologies reported as applied in all the academic documents under analysis. This figure reveals that a significant proportion of the studies were based on a qualitative methodology (59\%), followed by mixed methods $(23 \%)$, and quantitative methods $(18 \%)$.

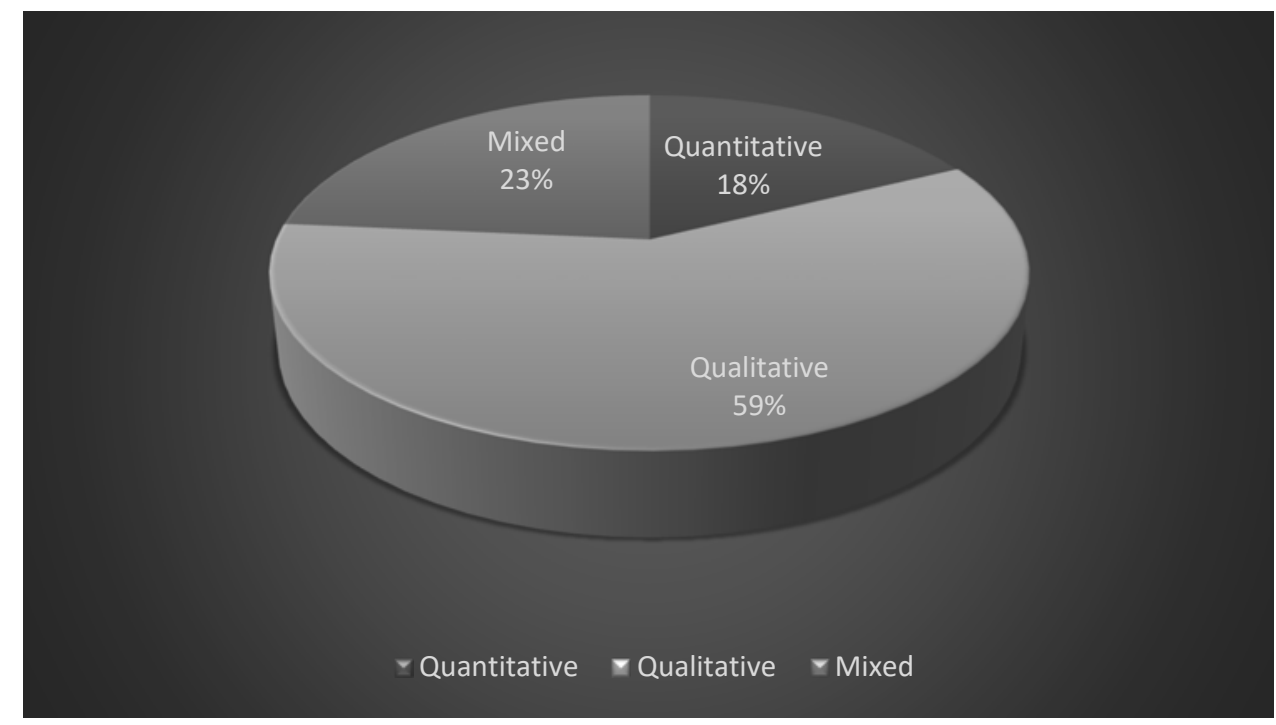

Figure 7. Methodologies of documents reviewed Source: Authors

\section{2) CLUSTER ANALYSIS}

The limited number of documents published on astrotourism did not permit analysis using data processing software. Thus, the first step was to input the titles and their 
abstracts into TreeCloud software that creates word clusters from a text, arranging them in a tree that reflects their semantic proximity. From the resulting word tree, we grouped the keywords that comprise each cluster in coloured circles, each colour corresponding to a different cluster and subcluster, for better identification (see Figure 8).

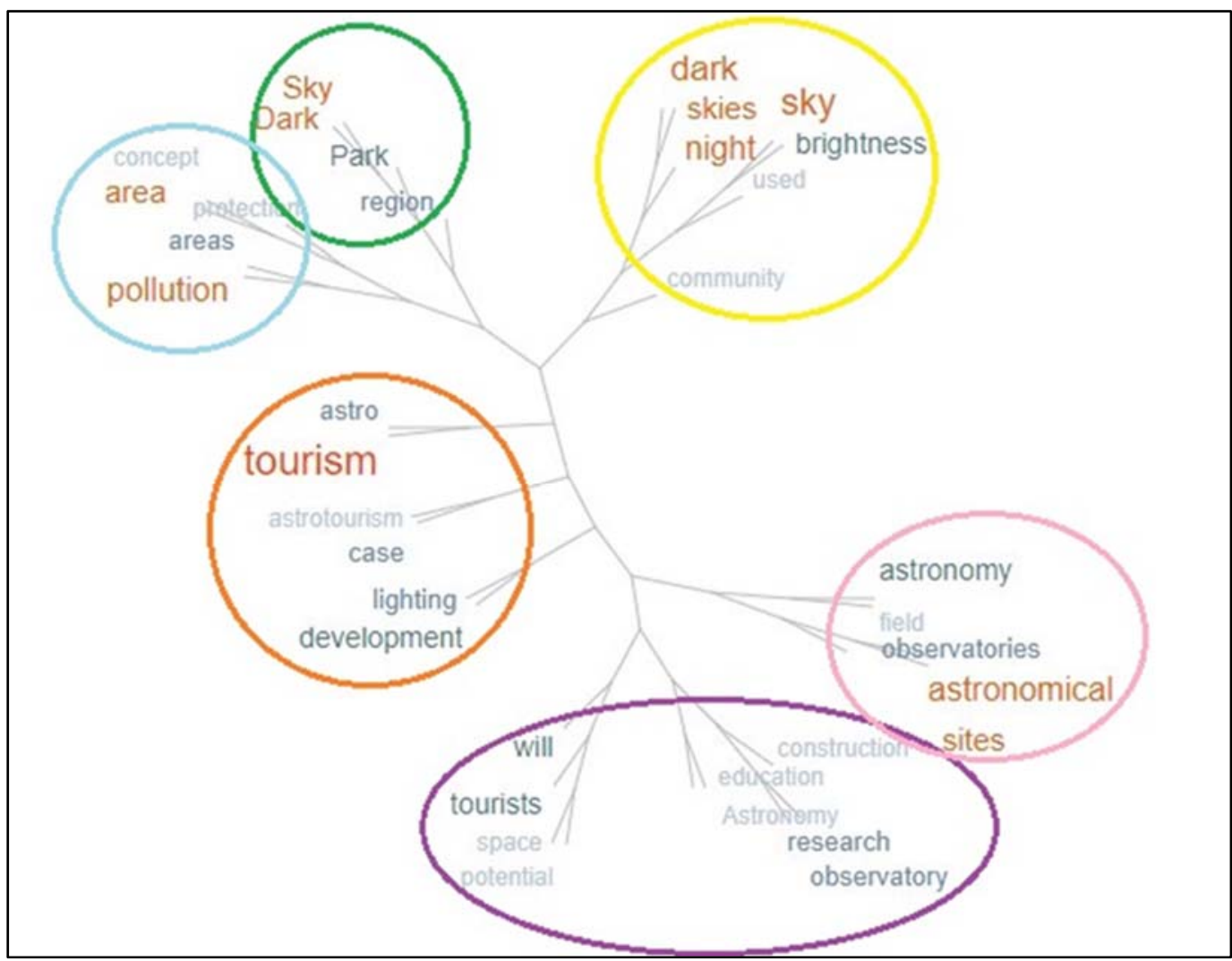

Figure 8. Word tree for titles and abstracts of 42 documents analysed Source: Authors

Based on Figure 8 above and an in-depth reading of the sample of 42 documents, these were grouped into 3 clusters and 4 subclusters in order to systematise the content of the publications reviewed. The clusters were labelled as follows: (1) conceptualisation of astrotourism, (2) opportunities, sustainability and tourism resources and (3) global experiences. Cluster 3 comprised four subclusters: (3.1) religion, knowledge and research; (3.2) education, workshops and certifications; (3.3) astronomy and aurora borealis and (3.4) innovation, regions and sustainable tourism. Figure 9 provides a schematic illustrating this connection between the themes of the clusters and subclusters and the colours that correspond to their keywords grouping. 


\section{1 -Conceptualisation of astrotourism (green)}

2 - Opportunities, sustainability and tourism resources (blue)

\section{3- Global experiences}

-3.1 - Religion, knowledge and research (purple)

-3.2 - Education, workshops and certifications (orange)

-3.3 - Astronomy and aurora borealis (pink)

-3.4 - Innovation, regions and sustainable tourism (yellow)

Figure 9. Characterisation of clusters and subclusters Source: Authors

Table 2 was constructed to synthesise and clarify each cluster's composition. The authors in each cluster are listed, as well as the clusters' labels.

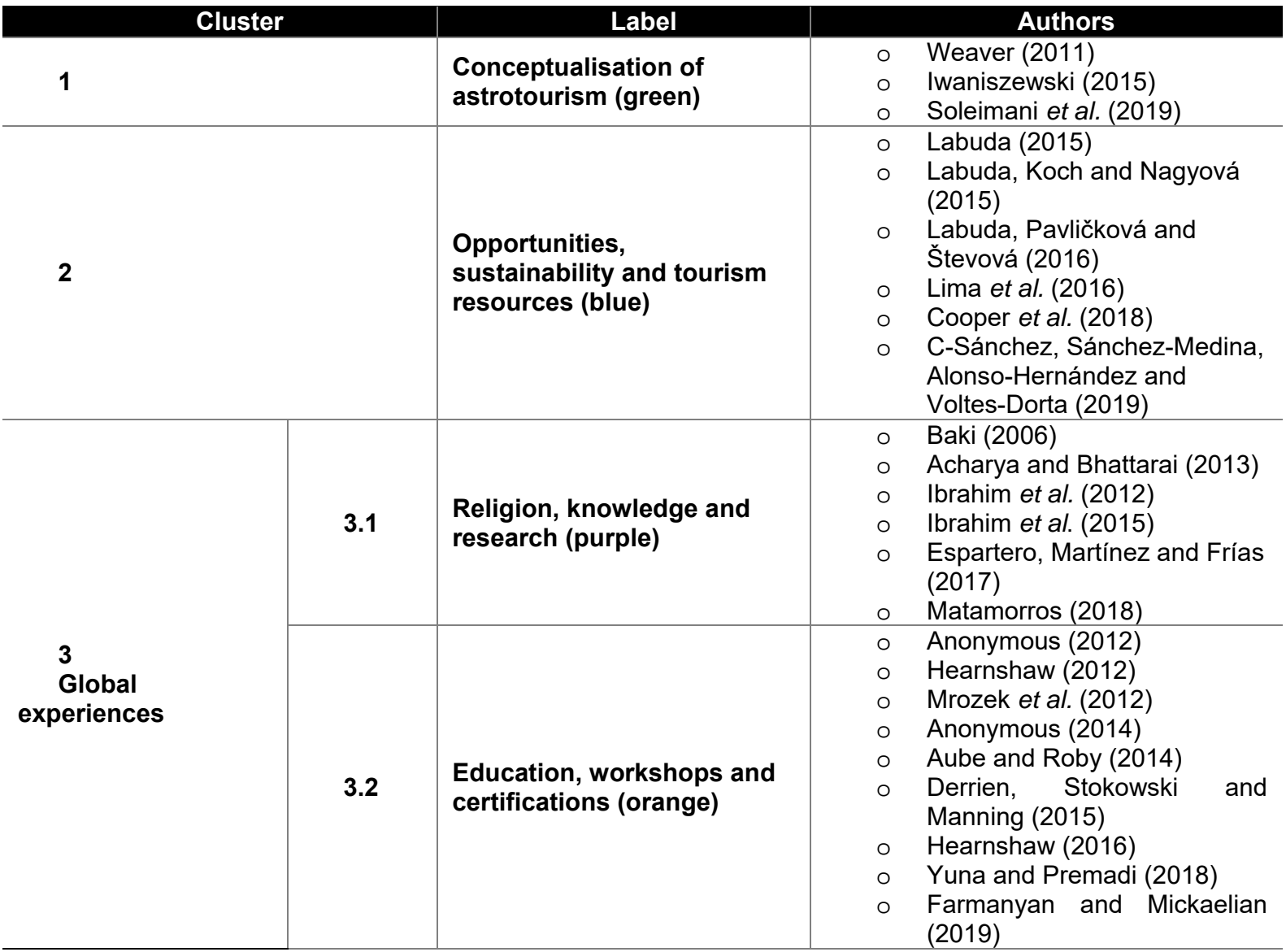




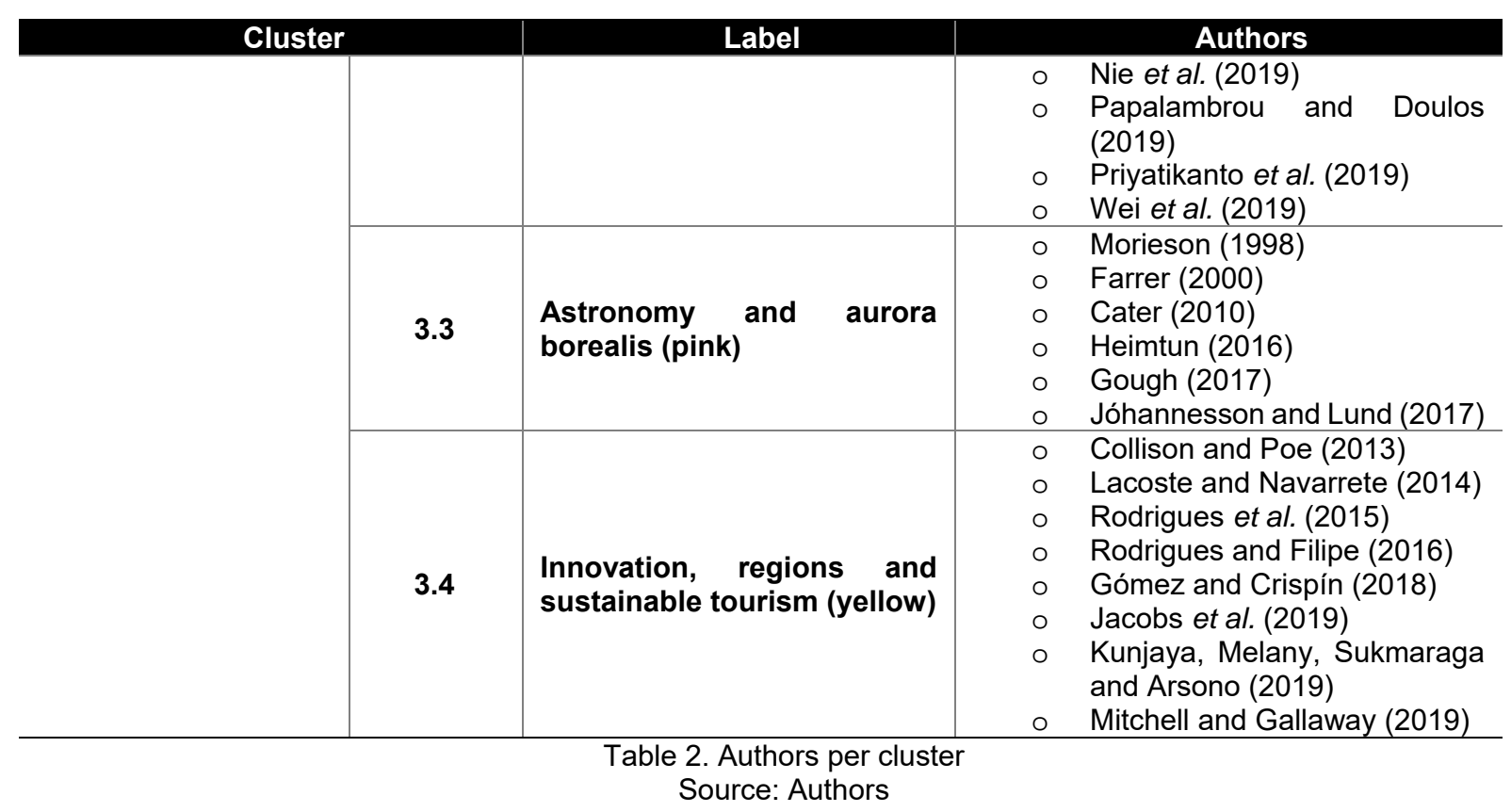

\subsection{1) CLUSTER 1 (GREEN): CONCEPTUALISATION OF ASTROTOURISM (THREE DOCUMENTS)}

The first cluster, as its label indicates, relates to the definition of the term astrotourism. No consensus has been reached in the academic community on this concept's theoretical characterisation. This cluster thus refers to three documents that address the complexity of defining astrotourism.

Human history reveals a deep connection to the stars that has shaped societies, fascinated individuals and fostered religiosity, embodying an ancient yet still present alliance, according to Iwaniszewski (2015). The recent appearance of astrotourism makes a conceptual framework difficult to form due to stakeholders' weak notion of limits and lack of stabilised parameters or even frontiers. Some benchmarks are anchored in a set of activities, conventions, projects and resolutions implemented by UNESCO (1972; 2003; 2005) and the Astronomy and World Heritage project in 2003. In addition, the Universal Declaration of Human Rights for Future Generations (UNESCO, 1994) stressed that:

“(...) people belonging to future generations are entitled to an undamaged earth, including pure heavens; they are entitled to their appreciation as the foundation of human history, culture and the social ties that make each generation and individual a member of the human family." 
Subsequently, people have developed a growing appreciation for - in conjunction with the consequent world heritage status of - the night sky. Overall, individuals are gradually becoming more aware of pollution in general and light pollution more specifically, which has also generated new ethical standards and contributed to the emergence of novel tourism offers. In conjunction with developing the necessary definitions to establish astrotourism's theoretical foundations, Soleimani et al. (2019) position this new form of tourism within the SIT framework. The cited authors base their conclusion on tourists' particular interest in activities related to the night sky (e.g. celestial phenomena and astrophotography).

In addition, the encompassing conceptual framework includes novel designations and official certifications that have emerged regarding global communities, parks and protected areas. The central aim is to preserve the night sky and promote astrotourism based on, among others, dark-sky international parks, dark-sky international reserves, starlight reserves, starlight tourism destinations, starlight villages, ecotourism and astronomy. These strategies could be combined with UNESCO's global framework to ensure astrotourism is a well-thought-out, sustainable and coherent phenomenon (Weaver, 2011).

\subsection{2) CLUSTER 2 (BLUE): OPPORTUNITIES, SUSTAINABILITY AND TOURISM RESOURCES (SIX DOCUMENTS)}

The second cluster is made up of a total of six documents, whose themes match the concepts in the cluster's label. The topics covered in this category are somewhat recent, as can be seen from the publication dates of the main documents featured, with the oldest articles dating from 2015. A perusal of the studies in this cluster confirmed that, although cultural links with the night sky have been maintained, pollution currently prevents two-thirds of the world's population from seeing the stars. Thus, universal patterns of logic maintained from time immemorial are being subverted (Lima et al., 2016).

As a result, the movement in favour of night sky protection and enhancement of astrotourism has grown, especially in North America and Europe. This undertaking has been promoted by institutions associated with this topic and focused on widely 
recognised natural spaces and areas in which the night sky is perceived as a scarce, precious and protected resource. This movement has fostered people's rediscovery of starry skies (C-Sánchez et al., 2019).

Rural areas are also configured as reservoirs of unspoilt skies, offering unique opportunities for tourists and local communities (Cooper et al., 2018; C-Sánchez et al., 2019) who see pollution as a threat to tourism and contemplation of celestial phenomena (Labuda, 2015; Labuda et al., 2015). These attitudes can entail difficulties for development projects and yet, concurrently, provide incentives for regional cooperation and partnerships, according to Labuda et al. (2016).

When astrotourism is positioned and framed as a SIT, this niche provides highly personalised tourism experiences (Cooper et al., 2018) associated with learning. Tourists' imaginations are stimulated, and they feel a sense of discovery when observing the deep sky, which awakens in them new talents and intellectual motivations. The development of this niche's products and the associated SIT allows the tourism industry to offer more competitive, differentiated offers able to satisfy the needs, desires and expectations of tourists with particular interests. Astrotourism also provides communities with a growing feeling of participation, and tourism developers can introduce a fresh phase of concern about and real contributions to meeting human needs and joining in development projects (Cooper et al., 2018).

Innovative models have contributed to astrotourism's increasing growth, which were developed to achieve a sustainable balance between the profitable use and protection of natural resources. These models are particularly focused on the problem of light pollution and the need to measure the night sky's brightness levels in order to offer quality products. For example, C-Sánchez et al. (2019) developed and tested an accurate method of predicting the night sky's short-term darkness, allowing tourists to gather in advance information about the places they intend to visit and thus more fully guaranteeing quality starry skies.

Cooper et al. (2018) see astrotourism as one of the most effective ways of bringing visitors closer to nature and gaining a better understanding of the physical world's systems and dynamics. Because of the pressures this niche tourism can exert, it may become a catalyst for a greater mobilisation of protectionist measures to ensure an appropriate enjoyment of natural spaces, balanced ecosystems and community development. 


\subsection{3) CLUSTER 3: GLOBAL EXPERIENCES (33 DOCUMENTS)}

The works included in this third cluster were identified by reading a set of documents with a variety of approaches, theories and practical examples of concepts' application. Fundamentally, these documents describe specific cases and the realities encountered during research and the ways methods favour the areas around the world in which the approaches were applied. The results translate into the following subtopics:

1. Religion, knowledge and research

2. Education, workshops and certifications

3. Astronomy and aurora borealis

4. Innovation, regions and sustainable tourism

\subsubsection{1) Sub-cluster 3.1 (purple): religion, knowledge and research (six} documents)

The first subcluster of this last section consists of six documents whose content is related to the links between astrotourism, religion and knowledge. The oldest publication is from 2006 and the most recent from 2018. Regarding the content analysed, the examples described are from Malaysia, Australia and Nepal.

Ibrahim et al. (2015) highlight astrophysical observatories and their various functions. The latter include, among others, research, management of Islamic practices and rituals, astronomy studies, lunar observations, sightings, experiences, tourism destinations and definitions of the earliest months of the year (i.e. Ramadan, Syawwal and Zulhijjah). Another article by Ibrahim et al. (2012) addresses in detail the characteristics of Malaysia's Al-Khawarizmi Complex, as well as key criteria that meet the requirements of an Islamic observatory. The latter cited authors sought to contribute a best practices guide to encourage the development of other similar observatories in Malaysia.

A third article written by Acharya and Bhattarai (2013) in Nepal focuses on astronomy's centrality in that country's society and education sector. Nepalese society is structured based on astronomical beliefs, which are widely popular and recognised. 
In another geographical location, Espartero et al. (2017) examined the issue of astrotourism centred around the Andalusian Astronomy Observatory (AAO), which was designed to fill the gap between professional and amateur observatories. The AAO was built to be an intermediary facility that facilitates astrophysics research while carrying out important initiatives in astronomy's dissemination through exhibitions and observations open to the public, as well as seeking to attract investment.

Chile also has an astronomical observatory, the European Observatory of Southern Chile, built to certify dark and pollution-free skies. This facility has generated a growing demand for astrotourism activities, resulting in a partnership between the observatory and the Chilean government to support the development of astronomy nationwide. The associated programmes aim to turn Chile into an astrotourism destination of excellence admired and recognised worldwide for its activities' attractiveness, quality, variety and sustainability (Matamorros, 2018).

The final item is an article by Baki (2006) that discusses African perspectives on astronomy based on indigenous knowledge about the night sky. This information is commonly used to address local challenges such as food security and periodic natural phenomena such as droughts and floods. Locals use their understanding of the sky to cope with these events with reference to the stars' positions, which are believed to change plants and animals' behaviour and predict the coming seasons' weather. Because the value of indigenous astronomical knowledge is recognised and treated as an intrinsic part of African cultures, these traditional indicators may give rise to interdisciplinary discourses. The results can benefit communities through environmental protection measures and increased tourism.

\subsubsection{2) Subcluster 3.2 (orange): education, workshops and certifications}

\section{(13 documents)}

The second subcluster's documents focus on aspects related to education, workshops and site upgrades with a view to obtaining certification. This subcluster contains the most publications (13), which are largely quite recent - falling between 2012 and 2019.

An analysis of these documents revealed that many authors concentrated on the certification aspects of dark-sky and starlight parks and reserves in extremely different 
countries such as Armenia, Poland, the Czech Republic, New Zealand and Slovakia. The researchers praise local communities and institutions' involvement, experts' engagement in discussions during conferences, workshops and other related meetings and efforts to attract more visitors (Hearnshaw, 2012; 2016; Mrozek et al., 2012; Farmanyan \& Mickaelian, 2019).

Other perspectives are considered based on experiences in the Nossentiner/Schwinzer Heide Natural Park in Germany and in China's Fujian province and other places, as well as Greece's Parnon Mountains and Indonesia. Studies have also focused on measuring brightness and light, inventorying suitable places for nighttime observations, introducing lighting plans and, most commonly, defining rules and guidelines for configuring surrounding lighting (Yuna \& Premadi, 2018; Nie et al., 2019; Papalambrou \& Doulos, 2019; Priyatikanto et al., 2019; Wei et al., 2019).

Light pollution is an unavoidable theme in astrotourism development, and researchers such as Aube and Roby (2014) have conducted studies using specific brightness measurement models. The proposed methods facilitate investigations of artificial light's effects in the night sky, before and after the creation of dark-sky reserves. For instance, the Mont Mégantic Observatory area in Canada serves as an example that guides the associated reserve and other locations' management.

This set of academic documents supports the conclusion that astronomical tourism's main objectives are to establish dark-sky and starlight parks and reserves and to implement measures to protect the night sky by reducing light pollution (Hearnshaw, 2012; Mrozek et al., 2012; Wei et al., 2019). Overall, the approaches reported seek to highlight this valuable resource's importance and encourage the implementation of organisational standards to ensure appropriate policies that are beneficial to tourism activities and individuals' welfare. One example of this is the Acadia National Park in the United States, which is a dark-sky location where park management organisations and local communities work together to protect the sky from light pollution and encourage local development (Derrien et al., 2015).

Excellent quality night skies can already be enjoyed that are almost totally free of light pollution, such as the Dark-Sky Aoraki Mackenzie International Reserve, which is the fourth largest in the world, with 400 square kilometres of dark skies in New Zealand (Anonymous, 2012). Another example is the Dark-Sky Northumberland International Park, which is Europe's largest area of protected skies, with 1,500 square kilometres, 
in the United Kingdom. This park imposes limits on exterior lighting around the park to ensure the night skies' visibility and darkness (Anonymous, 2014).

\subsubsection{3) Subcluster 3.3 (pink): astronomy and aurora borealis (six} documents)

The penultimate subcluster contains documents on astronomy and observations of other celestial phenomena such as aurora borealis. This set of six investigations includes the first publication on astrotourism in 1998, as well as one of the most recent from 2017. An analysis of these works revealed that humans' contact with and experiences related more or less directly with the sky are manifested through astrotourism.

Activities focus on observations of the stars using a telescope or the naked eye and of comets and eclipses, as well as astrophotography, visits to public astronomical observatories, archaeotourism, ethno-tourism and astronomical calendar events, among others. In this context, the aurora borealis are closely associated with northern lights tourism. Astrotourism thus provides a variety of approaches to the night sky that are already part of regular economic activities, including its enjoyment by important niche market segments.

This subcluster's documents focus on the sensory, affective and symbolic aspects of tourists' experiences (Jóhannesson \& Lund, 2017). Researchers dive into the ways this tourism of light and darkness meanders through wild, imagined and remote territories, configuring emotional, unexpected and singular encounters with nature (Heimtun, 2016). This profile of experiences is also being applied to space tourism, whose business model has been maturing as providers seek a new conception of space tourists for the future. Although for now space tourism is still an offer available to the elite (Cater, 2010), this niche may be able, in the future, to provide more diverse and accessible opportunities.

Given astrotourism's emergence as a SIT and the growing demand for experiences related to starry skies, light pollution is a subject naturally associated with this topic for some time. Astrotourism is practiced in remote places with specific characteristics, such as clean, high quality night skies providing direct observations of celestial phenomena. Gough (2017) describes the literary work of Bob Mizon, one of the world's 
best-known activists in the fight against light pollution. Mizon describes all the places in the United Kingdom and United States where people can still contemplate perfect or almost perfect night skies. This information makes Mizon's book an invaluable guide for readers seeking out these two countries' dark-sky places.

The articles on Australia (Johnson, 1998), in turn, provide reports of fragmentary traditional components characterised by scattered elements such as lists of stars, asterisms, constellations or beliefs (Morieson, 1998; Farrer, 2000), which do not form a consolidated historical matrix. Nevertheless, these investigations provide proof that humans' connection with the sky's luminaries is ancestral. In spite of all the scientific and technological advances brought by recent developments, peoples still exist who possess a more traditional knowledge of the night sky. These communities are guided in other dimensions by the stars and varied celestial phenomena regarding how to overcome daily life challenges.

4.2.3.4) Subcluster 3.4 (yellow): innovation, regions and sustainable tourism (eight documents)

The last subcluster deals with research mainly related to innovation, territory and tourism's sustainability, making up a total of eight documents published between 2013 and 2019. Within the topic of tourism resources, three articles make the transition from theoretical to practical examples of projects. This research takes into account the organised tourism resources central to tourism development models in which astrotourism emerges - or is intended to emerge - as a regional lever (Collison \& Poe, 2013; Rodrigues \& Filipe, 2016). Specific examples include the Pisco Route in Chile, which is an old itinerary covering over 6,000 kilometres including the city of La Serena and which runs through the Southern Cone region. This route is a complementary alternative to sun and beach tourism, which plays an important role in wine and rural tourism (Lacoste \& Navarrete, 2014).

In addition, Jacobs et al. (2019) describe how unique experiences such as astrotourism can be considered a viable mechanism for producing sustainable development in rural settings in South Africa. The unique landscape - together with sites of significant astronomical interest and importance - provide an ideal opportunity to develop on-site astrotourism activities as a niche market offer. However, Jacobs et 
al. (2019) argue that astrotourism products' successful development depends largely on destinations' level of development. The cited authors suggest partnerships should be created between entrepreneurs, tour operators and astronomers in order to improve South Africa's tourism offer and promote astrotourism while contributing to rural tourism's sustainable development.

Kunjaya et al. (2019) draw attention to the celestial events in Indonesia that have taken place in recent years and that demonstrate the country's potential for attracting visitors interested in astrotourism. This type of tourism is in line with national government programmes, and it is considered to have great economic potential. Kunjaya et al. (2019), nonetheless, stress the need to develop an astrotourism ecosystem in Indonesia. Officials can then optimise the benefits arising from astrotourism's contribution to the tourism industry at not only an economic development level but also a local sociocultural level.

Gómez and Crispín (2018) further define astrotourism as a new aspect of world tourism but focus on this niche's structure in Chile's Coquimbo region. The importance of this type of activities in the region is due to astrotourism's association with the physical environment's particular characteristics and articulation through natural resources, infrastructure, accessibility and other regional tourism features. Astrotourism is also connected with the climate, land features, accommodations and observatories. Coquimbo thus has all the characteristics needed to make it a particularly excellent area for practicing astronomical tourism.

In Portugal, the Alqueva Dark-Sky Reserve was classified by the Starlight Foundation as the first starlight tourism destination. This achievement was the result of strategies based on community, environment and varied economic, municipal and institutional agents, who pushed to differentiate tourism using the artificial lake of Alqueva. These partnerships were essential for astrotourism's appearance in the region, which interacted well with the existing business models (Rodrigues et al., 2015).

Another example comes from the United States, more specifically, the Colorado Plateau. Mitchell and Gallaway (2019) studied astrotourism's impact on national parks in this area, demonstrating the significant positive effect of interest in the night sky on the local economy. A 10-year forecast estimates that economic results will be 
excellent, including an expected increase in wages and the creation of new jobs in the region.

\section{RESPONSES TO RESEARCH QUESTIONS, DISCUSSION OF RESULTS AND SUGGESTIONS FOR FUTURE RESEARCH}

\section{1) RESPONSES TO RESEARCH QUESTIONS}

This literature review sought to answer three predefined research questions. After analysing the results, the first question (i.e. What are the most studied subjects in previous research on astrotourism?) could be addressed. The documents analysed were divided into clusters to identify the most frequently studied topics within astrotourism. The themes included (1) conceptualisation of astrotourism; (2) opportunities, sustainability and tourism resources; (3.1) religion, knowledge and research; (3.2) education, workshops and certifications; (3.3) astronomy and aurora borealis and (3.4) innovation, regions and sustainable tourism.

The largest proportion of articles on astrotourism are part of cluster 3.2, which comprises 13 documents related to education, workshops and certification. These publications conduct an inventory of areas with potential for astrotourism in terms of the sites' physical attributes and night sky's brightness values, as well as focusing on the problem of light pollution.

The second research question was as follows: What are the characteristics of previous research on astrotourism? The specific criteria examined were number of publications per year, types of documents, most cited articles, authors with the most publications, countries and continents with the most publications and most used research methodologies.

Regarding the number of publications per year, the first study published on astrotourism dates to 1998 , but academic production in this field only began to increase in 2012. The 3 years with the highest number of publications were 2019 with 10 documents, 2015 with 6 and 2012 with 4 (see Figure 4 above). The most common type of documents published on astrotourism are academic papers (57\%), followed by conference publications (see Figure 5 above). 
Of the documents analysed for this literature review, the most frequently cited have 22 citations each, both of which were relatively recent (i.e. 2011 and 2013) and indexed in Scopus. Weaver's (2011) 'Celestial Ecotourism: New Horizons in Nature-based Tourism' is part of cluster 1 (i.e. conceptualisation of astrotourism). Collison and Poe's (2013) “'Astronomical Tourism”: The Astronomy and Dark Sky Program at Bryce Canyon National Park' is part of cluster 3.2 (i.e. education, workshops and certification) (see Table 1 above).

Regarding the authors with more publications on astrotourism, Labuda comes in first with 3 articles, and 4 other authors published 2 documents on this topic (i.e. Hearnshaw, Ibrahim, Safiai and Rodrigues) (see Figure 6 above). The countries with the most studies in this field are the United Kingdom and United States with 5 publications each, although the statistics by continent show that Europe leads with 17 publications (see Figures 7 and 8 above). Finally, the analysis of the documents' methodologies revealed that a large part of the research $(59 \%)$ was based on qualitative methods, followed by mixed methods (23\%), and quantitative methods $(18 \%)$.

The third research question was as follows: What gaps exist in research on astrotourism that future studies can address? Based on the documents' contents and the descriptive statistics generated, future researchers need to define and delimit the concept of astrotourism and differentiate its activities' typologies (e.g. land observations vs space tourism). In addition, astrotourism relies on sensations and experiences that can be associated with other initiatives, so an effort should be made to develop different tourism activities that complement each other in order to provide visitors with complete, innovative and attractive offers.

The creation of dark-sky and starlight parks and reserves also needs further study since these initiatives facilitate night sky observations away from cities' blinding lights. Researchers should focus on astrotourism's effects within the framework of sustainable tourism and its relationship with host communities, as well as the environmental impacts generated in the regions surrounding these certified sites. Another topic of interest is astrotourism's integration into other tourism products that already exist. To address other shortcomings, the results also indicate that future studies need to concentrate on the procedures to be followed that could lead to starry skies becoming part of UNESCO classifications (see Table 3 above). 


\section{2) DISCUSSION OF RESULTS AND SUGGESTIONS FOR FUTURE RESEARCH}

This literature review's findings support several conclusions, the first of which is related to the problems surrounding the definition of a single conceptualisation of astrotourism. Although no ideas or thoughts appear to be in direct conflict, the lack of consensus about a homogeneous definition continues to produce divisive opinions. This issue can be explained by how, although astrotourism's conceptualisation includes positive, contemporary and socially accepted goals, this field of research only recently began to develop unique approaches and models (Atkinson, 2007; Charlier \& Bourgeois, 2013; Fayos-Solá et al., 2014; Matos, 2017; Cooper et al., 2018).

Nonetheless, three points of view stand out in the overall process of astrotourism's conceptualisation. First, Fayos-Solá et al.'s (2014) definition highlights the value of night skies and tourism destinations' astronomical and archaeoastronomical heritage. This niche tourism also contributes to knowledge sharing and human capital formation with regard to visitors and host communities, thus contributing to local development. Second, Charlier and Bourgeois's (2013) conceptualisation recognises astrotourism's ancestral links and identifies astrotourists as people seeking new sensory and cognitive experiences to complement their visits. Last, Soleimani et al. (2019) position astrotourism as a SIT - well away from mass activities - as this niche is renowned for recognising tourists' need to observe specific celestial phenomena. Astrotourism provides unique experiences that can be considered niche market products.

Based on the various conceptual definitions identified during the present study's review of the 42 selected documents, all the authors cited (e.g. Korlević \& Krajnović, 1999; Charlier \& Bourgeois, 2013; Fayos-Solá et al., 2014; Ibrahim et al., 2015; Iwaniszewski, 2015; Soleimani et al., 2019) converge on a single point. They identify astrotourism as tourism activities centred around astronomy and the observation of celestial phenomena, whether by professional or amateur astronomers. A consensus has also been reached that astrotourism is a growing, increasingly popular phenomenon.

The number of documents analysed in the present study was small, but together they confirm that, at the level of conceptualisation, astrotourism is still in an embryonic 
phase characterised by a poorly stabilised definition and quite tenuous outlines. Regarding the delimitation of the relevant activities' theoretical boundaries, a more comprehensive, complete conceptual framework is needed, so the current findings include a fresh definition of astrotourism based on the 42 articles, which is presented in the following paragraph.

Astrotourism corresponds to the expanding practice of diverse tourism activities that are innovative, integrated and attractive and that focus on the observation of night skies and celestial phenomena, especially in natural spaces. These activities contribute to local communities' involvement, empowerment and participation and the development of low-density regions, promoting their economy, environment and sustainability. Viewed as a millennial trend of humanity, astrotourism seeks to ensure that starry skies are experienced and valued by visitors and tourists, in terms of the diverse associated historical, social, scientific, contemplative, symbolic and transversal heritage. This rich legacy contributes to tourism destinations' certification and ecological values and visitors' cognitive and emotional experiences.

In relation to the path followed by astrotourism up to the present, the documents analysed support the conclusion that this phenomenon has only caught scholars' attention in the last three decades. The publication of research conducted in this field between 1998 and 2019 shows that a greater quantity of academic publications appeared from 2012 onwards as a result of the tourists' growing interest in activities related to the night sky combined with the academic community, astronomers, ecological trends, movements among associations and networks of parks and nature reserves to focus efforts on varied attempts to reduce light pollution. These are probably the reasons why most studies in this area are concentrated in the United States of America and the United Kingdom, developed countries with high population densities, where the negative effects of light pollution have been noticed faster and the need to protect the night sky through the creation of reserves and certified sites to allow its observation was felt earlier than in smaller countries. Humanity only recently truly became aware of the dramatic trajectory of events that has obscured the starry skies, thus turning its attention for the first time to the worrying problem of light pollution.

A regulatory framework is needed that can guide the process of protecting the skies and meeting the growing demand for astrotourism activities. Guidelines could 
contribute to the certification of protected natural sites by institutions such as IDA and the Starlight Foundation (e.g. dark-sky and starlight parks and reserves). Protected areas can already be found all over the globe, and they have increasingly shaped the configuration of tourism visitation and business mobilisation proposals.

These projects count on a number of foundations' support, including ICOMOS, UNESCO and the WTO. Certified sites facilitate the observation of stars and other celestial phenomena, embodying an increased demand fostered, for instance, by visits to Nordic aurora borealis and opening the doors for everything these activities represent. One possible approach is for UNESCO to classify the night sky in general as World Heritage.

Parallel to this trend towards valorisation and identity construction, the night sky also started to be seen as a tourism resource capable of bringing benefits to local communities through regional socioeconomic and cultural development. Astrotourism has been categorised by some scholars as a SIT and thus as a niche market product increasingly sought after by tourists with unique needs and desires (Collison \& Poe, 2013; Rodrigues \& Filipe, 2016; Soleimani et al., 2019). Given the growing demand for activities related to the night sky, astrotourism destinations' managers must understand which intentions, behaviours and selection processes precede visitors' choices and contribute to the formation of these locations' affective image. This knowledge will allow the supply to be adapted to meet tourists' expectations and needs. Research in this field, therefore, is useful to destination managers and regions seeking to develop strategies, as well as benefiting local stakeholders.

In addition, astrotourism is part of low-density regions' sustainable tourism profile. Given the scarcity of empirical research based on theories and regional development models, scholars could also study astrotourism's role in this context from the perspective of collaborative networks. These investigations need to be supported by triple, quadruple and quintuple helix innovation models, which already occupy a prominent place in regional development policies and which are widely accepted by the academic community. This approach can contribute to local astrotourism offers' diversification, development and certification, fitting in with the literature's most recent themes (i.e. clusters 2 and 3.4).

The increased interest in astrotourism, together with site certification, has forced experts to think about sustainable ways to use night sky resources. The goal is to 
enable community development, generate wealth and attract tourists without harming ecosystems (Jacobs et al., 2019). Researchers have reported on projects all over the world related to the construction of astrophysical observatories to serve scientific purposes, religious practices, astronomy and the development of tourist experiences. Publications highlight the night sky's importance in people's daily life and improved wellbeing, positioning starry skies as a valuable marketable resource when optimal environmentally friendly conditions are provided (Ibrahim et al., 2012; Ibrahim et al., 2015; Espartero et al., 2017; Gómez \& Crispín, 2018).

However, more studies are needed on how astrotourism can complement other existing tourism activities. Although environmental issues are one of the main concerns raised during discussions about astrotourism, researchers must provide a deeper understanding of this niche tourism's impacts on the environment and community, regional and national development.

The present literature review aggregated all the existing information on astrotourism from the most varied perspectives and contexts, facilitating conclusions about the level of research on this topic and paths to be followed in the future. Currently, astrotourism's conceptualisation needs to be stabilised and a stronger focus put on with the environmental concerns linked to this topic and the associated problem of light pollution. Scholars must seek to preserve and enhance astronomical and archaeoastronomical heritage and investigate the effects of certified sites on astrotourism as a way to protect the environment and ensure sustainable tourism practices and community development.

Astrotourism not only translates into a new tourism concept but also provides added value to the regions or contexts in which it can be introduced. This niche tourism boosts local economies, promotes regions and/or countries and combines sustainable development practices. Astrotourism thus should be subjected to further investigations from multiple perspectives (see Table 3 ) in order to receive the recognition it deserves. 
1. Conceptualisation of astrotourism

2. Opportunities, sustainability and resources

- Stabilise and outline a definition of astrotourism

- Define the process to follow so that the night sky can be classified by UNESCO as World Heritage

- Identify and characterise certified sites' effects and contributions of astrotourism practices (i.e. dark-sky and starlight parks and reserves) regarding the environment to encourage sustainable tourism practices and protect host communities

- Examine astrotourism's role in regional development from a SIT perspective

- Conduct empirical research on astrotourism based on collaborative networks and helix models (i.e. triple, quadruple and quintuple)

- Identify and characterise the behavioural antecedents of tourists' choices of astrotourism destinations (i.e. intentions, behaviours and selection processes) and these locations' affective image formation

3. Global experiences other existing tourism activities

- Investigate astrotourism's effects on the environment and community, regional and national development

Table 3. Suggested research by cluster

Source: Authors

\section{CONCLUSIONS}

This study assessed the current state of academic research on astrotourism using a qualitative methodology. The literature review analysed all the documents on this topic published until 2019, thereby obtaining a comprehensive understanding of the field of astrotourism's evolution and contributing suggestions of new research paths that could complement the existing empirical framework.

Despite the absence of a consensual definition of astrotourism, the results show that, at a regional level, this niche has the potential to function as a regional lever as a non-mass tourism alternative to other types of activities. Astrotourism has distinguished itself by offering unique experiences that combine quality night skies' characteristics with appropriate attributes and regional infrastructure, which can be associated with other complementary products (Collison \& Poe, 2013; Lacoste \& Navarrete, 2014; Rodrigues \& Filipe, 2016). Given the present findings, astrotourism has potential benefits at the tourism, education, religion, sustainable development and cultural level.

This niche tourism has become increasingly popular, as the interest of academics and researchers increased, so experts need to understand more fully the starry skies' role in people's development, religion and daily lives. Researchers should investigate the impacts of the growing demand for this SIT, the factors that promote tourists' choice of astrotourism destinations and these locations' positive image. In addition, studies 
must analyse dark-sky and starlight parks and reserves' effects on sustainable and local development and efforts to get around the intensifying problem of light pollution (Jacobs et al., 2019).

Astrotourism's success depends not only on protecting the night sky but also on organising resources and creating partnerships between local players (e.g. entrepreneurs, tour operators, community representatives, destination managers and astronomers). In particular, network governance models can improve destinations' astrotourism offer and develop excellent, marketable and sustainable products (Jacobs et al., 2019). Astrotourism is, therefore, a growing phenomenon that, despite researchers' increased interest, still has a long way to go as an academic field, making this a challenging area with promising potential. The present literature review's findings contribute to this SIT's development by mapping the state of the art of publications on astrotourism and identifying new emerging lines of research that can ensure this phenomenon is studied more systematically.

\section{Acknowledgments}

This research project was supported by the FCT-Portuguese Foundation for Science and Technology [project UIDB/04011/2020].

\section{References}

Acharya, K.; Bhattarai, S. Space outreach in Nepal. Proceedings of the International Astronautical Congress, IAC, Vol. 12, Beijing, China, September 23-27, 2013, pp. 9757-9763.

Anonymous. New Zealand's dark sky reserve. Astronomy \& Geophysics, Vol. 53, No 4, 2012, p. 6

Anonymous. Northumberland Dark Sky Park. Astronomy \& Geophysics, Vol. 55, No 1, 2014 , p. 7. 
Atkinson, M. To Navigate Time: Contemplations on Sky and Land, an Australian Experience. In Marin, C.; Jafari, J. (Eds.). Starlight A Common Heritage. Canary Island, Spain: Starlight Initiative, Instituto de Astrofísica de Canárias (IAC), 2007, pp. 93-101. Retrieved from https://issuu.com/pubcipriano/docs/starlightcommonheritage [accessed 6 May 2021].

Aube, M.; Roby, J. Sky brightness levels before and after the creation of the first International Dark Sky Reserve, Mont-Megantic Observatory, Quebec, Canada. Journal of Quantitative Spectroscopy \& Radiative Transfer, Vol. 139, 2014, pp. 52-63.

Baki, P. Astronomy in the cultural heritage of African societies. Proceedings of the International Astronomical Union, Vol. 2, No SPS5, 2006, pp. 99-102.

Begley, S. Night of a Thousand Stars, 2016. Retrieved from https://time.com/4341408/night-of-a-thousand-stars/ [accessed 6 May 2021].

Cater, C.I. Steps to Space: opportunities for astrotourism. Tourism Management, Vol. 31, No 6, 2010, pp. 838-845.

Challéat, S. Nighttime: A new topic for geography [La nuit, une nouvelle question pour la géographie]. Bulletin d'Association De Geographes Francais, Vol. 88, No 2, 2011, pp. 183-196.

Charlier, B.; Bourgeois, N. "Half the park is after dark". Dark sky parks and reserves: New concepts and tools to grant nature heritage status [«Half the park is after dark». Les parcs et réserves de ciel étoilé: Nouveaux concepts et outils de patrimonialisation de la nature]. Espace Geographique, Vol. 42, No 3, 2013, pp. 200-212.

Collison, F.M.; Poe, K. "Astronomical tourism": The astronomy and dark sky program at Bryce Canyon National Park. Tourism Management Perspectives, Vol. 7, 2013, pp. $1-15$. 
Cooper, C.; Fayos-Solà, E.; Jafari, J.; Lisboa, C.; Marín, C.; Perdomo, Y.; Urosevic, Z. Case studies in technological innovation. In Fayos-Solà, E.; Cooper, C. (Eds.). The future of tourism: Innovation and sustainability. Cham: Springer International Publishing, 2018, pp. 111-127.

C-Sánchez, E.; Sánchez-Medina, A.J.; Alonso-Hernández, J.B.; Voltes-Dorta, A. Astrotourism and night sky brightness forecast: First probabilistic model approach. Sensors (Switzerland), Vol. 19, No 13, 2019.

Derrien, M.M.; Stokowski, P.A.; Manning, R.E. A Rhetorical Analysis of National Park Service and Community Leader Discourses about Night Skies at Acadia National Park. Journal of Park and Recreation Administration, Vol. 33, No 3, 2015, pp. 32-47.

Espartero, F.; Martínez, G.; Frías, M. Observatorio andaluz de astronomía. Revista Mexicana De Astronomia y Astrofisica: Serie de Conferencias, Vol. 51, Mazagón, Huelva, Spain, October 16-20, 2017, pp. 58-61.

Farmanyan, S.V.; Mickaelian, A.M. Astronomical Tourism Sites in Armenia. In Farmanyan, S.V.; Mickaelian, A.M.; Malville, J.M.; Bagheri, M. (Eds.). Astronomical Heritage of the Middle East. ASP Conference Series. Vol. 520, 2019, pp. 253-257.

Farrer, C.R. Night Skies of Aboriginal Australia: A Noctuary. American Ethnologist, Vol. 27, No 3, 2000, pp. 777-778.

Fayos-Solá, E.; Marín, C.; Jafari, J. Astrotourism: No Requiem for Meaningful Travel. PASOS, Revista de Turismo y Patrimonio Cultural, Vol. 12, No 4, 2014, pp. 663-671.

Gómez, J.D.P.; Crispín, A.S. Territorial structure of astronomical tourism in the region of Coquimbo, Chile. Revista Geográfica de America Central, Vol. 61E, 2018, pp. 181206.

Gough, M. Finding a Million-Star Hotel: An Astro-Tourist's Guide to Dark Sky Places. Observatory, Vol. 137, No 1258, 2017, pp. 138-138. 
Gumuchian, H.; Pecqueur, B. La ressource territoriale. Paris: Economica, 2007.

Hearnshaw, J. A new Starlight Reserve for the central South Island of New Zealand. Proceedings of the International Astronomical Union, Vol. 10, No H16, 2012, pp. 736. ISSN 17439213.

Hearnshaw, J.B. Mt john observatory: The first 50 years. Papers and Proceedings of the Royal Society of Tasmania, Vol. 150, No 1, 2016, pp. 1-8.

Heimtun, B. Emotions and affects at work on northern lights tours. Hospitality and Society, Vol. 6, No 3, 2016, pp. 223-241.

Ibrahim, I.A.; Ahmad, M.R.; Safiai, M.H.; Mujani, W.K. Islamic astronomy and the establishment of Al-Khawarizmi complex in Malaysia. Advances in Natural and Applied Sciences, Vol. 6, No 3, 2012, pp. 316-320.

Ibrahim, I.A.; Safiai, M.H.; Jamsari, E.A. Functions of astrofiqh observatories in Malaysia in solving astrofigh issues. Mediterranean Journal of Social Sciences, Vol. 6, No 1S1, 2015, pp. 112-119.

Iwaniszewski, S. Astrotourism and archaeoastronomy. In Ruggles, C. (Ed.). Handbook of Archaeoastronomy and Ethnoastronomy. New York: Springer, 2015, pp. 287-300.

Jacobs, L.; Du Preez, E.A.; Fairer-Wessels, F. To wish upon a star: Exploring Astro Tourism as vehicle for sustainable rural development. Development Southern Africa, Vol. 37, No 1, 2019, pp. 87-104.

Jóhannesson, G.T.; Lund, K.A. Aurora Borealis: Choreographies of darkness and light. Annals of Tourism Research, Vol. 63, 2017, pp. 183-190.

Johnson, D. Night Skies of Aboriginal Australia: A Noctuary. Australia: Sydney University Press, 1998. 
Korlević, K.; Krajnović, A. Astrotourism Development in Višnjan. Tourism and Hospitality Management, Vol. 5, No 1-2, 1999, pp. 85-96. Retrieved from https://hrcak.srce.hr/181928 [accessed 6 May 2021].

Kunjaya, C.; Melany; Sukmaraga, A.A.; Arsono, T. Possibility of astronomical phenomena to be used to support tourism industry. Journal of Physics: Conference Series, Vol. 1231, No 1, 2019, pp. 1-8.

Labuda, M. Utilization of dark sky parks in nature tourism. Public Recreation and Landscape Protection - With Man Hand in Hand! 2015 Conference Proceeding, Brno, Czech Republic, May 3-5, 2015, pp. 280-285.

Labuda, M.; Pavličková, K.; Števová, J. Dark Sky Parks - New impulse for nature tourism development in protected areas (National Park Muranska Planina, Slovakia). E-review of Tourism Research, Vol. 13, No 5-6, 2016, pp. 536-549.

Labuda, V.M.; Koch, R.; Nagyová, A. "Dark sky parks" as measure to support nature tourism in large protection areas - case study in the nature park "Nossentiner/ schwinzer heide". Naturschutz Und Landschaftsplanung, Vol. 47, No 12, 2015, pp. 380-388.

Lacoste, P.; Navarrete, S. An alternative of rural development: The Rout of Pisco as tourist resource (Elqui Valley, Chile). Idesia, Vol. 32, No 4, 2014, pp. 5-14.

Landel, P.A. Invention de patrimoines et construction des territoires. In Gumuchian, H.; Pecqueur, B. (Eds.). La ressource territoriale. Paris: L'Harmattan, 2007, pp. 149157.

Lima, R.C.; Pinto da Cunha, J.; Peixinho, N. Light pollution: Assessment of sky glow on two dark sky regions of Portugal. Journal of Toxicology and Environmental Health - Part A: Current Issues, Vol. 79, No 7, 2016, pp. 307-319. 
Longcore, T.; Rich, C. Ecological light pollution. Frontiers in Ecology and the Environment, Vol. 2, No 4, 2004, pp. 191-198.

Marín, C.; Jafari, J. Starlight: A Common Heritage. Canary Islands, Spain. Starlight Initiative Instituto de Astrofísica de Canarias (IAC), 2007. Retrieved from https://issuu.com/pubcipriano/docs/starlightcommonheritage [accessed 6 May 2021].

Marín, C.; Orlando, G. Starlight Reserves and World Heritage-Scientific, Cultural and Environmental Values. International Workshop and Expert Meeting Final Report, Fuerteventura, Canary Islands, Spain. Starlight Initiative, IAC and the UNESCO World Heritage Centre, 2009. Retrieved from https://issuu.com/pubcipriano/docs/finalreportfuerteventurasl [accessed 6 May 2021].

Marín, C.; Wainscoat, R.; Fayos-Solá, E. Windows to the Universe: Starlight, Dark-Sky Areas and Observatory Sites. In Ruggles, C.; Cotte, M. (Eds.). Heritage Sites of Astronomy and Archeoastronomy in the Context of the UNESCO World Heritage Convention. A Thematic Study. Paris, France: ICOMOS \& International Astronomical Union, 2010, pp. 238-245.

Matamorros, E. Astrotourism is booming in Chile. Astronomy \& Geophysics, Vol. 59, No 6,2018 , p. 5.

Matos, A.L. Terrestrial astrotourism - Motivation and satisfaction of travelling to watch the night sky. Master's thesis: Aalborg University, 2017. Retrieved from https://projekter.aau.dk/projekter/files/260343239/THESIS ASTROTOURISM PDF.p df [accessed 6 May 2021].

Mitchell, D.; Gallaway, T. Dark sky tourism: Economic impacts on the Colorado Plateau economy, USA. Tourism Review, Vol. 74, No 4, 2019, pp. 930-942.

Moher, D.; Liberati, A.; Tetzlaff, J.; Altman, D.G. Preferred reporting items for systematic reviews and meta-analyses: The PRISMA statement. Journal of Clinical Epidemiology, Vol. 62, No 10, 2009, pp. 1006-1012. 
Moher, D.; Shamseer, L.; Clarke, M.; Ghersi, D.; Liberati, A.; Petticrew, M.; Shekelle, P.; Stewart, L.; PRISMA-P Group. Preferred reporting items for systematic review and meta-analysis protocols. (PRISMA-P) 2015 Statement. Systematic Reviews Journal, Vol. 4, No 1 , 2015.2 Retrieved from https://systematicreviewsjournal.biomedcentral.com/articles/10.1186/2046-4053-41\#citeas [accessed 6 May 2021].

Morieson, J. Night Skies of Aboriginal Australia. Oceania, Vol. 69, No 2, 1998, pp. $142-$ 144.

Mrozek, T.; Kołomański, S.; Zakowicz, G.; Kornafel, S.; Czarnecki, T.L.; Suchan, P.; Kamiński, Z. Astro tourism: Astro Izery project. Proceedings of the International Astronomical Union, Vol. 10, No H16, 2012, pp. 737.

Nie, Y.W.; Lan, T.; Yu, M. Scenic Sites Selection in Dark-Sky Park Based on NPP/VIIRS: A Case Study in Fujian Province. In Patnaik, S. (Ed.). Proceedings of the 9th International Conference of Information and Communication Technology [ICICT2019], Vol. 154, 2019, pp. 798-805.

Nilsson, M.P. Primitive Time-Reckoning: A Study in the Origins and First Development of the Art of Counting Time Among the Primitive and Early Culture Peoples. Lund. Gleerup, 1920. Retrieved from https://archive.org/details/primitivetimerec00nilsrich/page/384/mode/2up [accessed 6 May 2021].

Papalambrou, A.; Doulos, L.T. Identifying, Examining, and Planning Areas Protected from Light Pollution. The Case Study of Planning the First National Dark Sky Park in Greece. Sustainability, Vol. 11, No 21, 2019, pp. 5963-.

Priyatikanto, R.; Admiranto, A.G.; Putri, G.P.; Elyyani; Maryam, S.; Suryana, N. Map of sky brightness over greater Bandung and the prospect of astro-tourism. Indonesian Journal of Geography, Vol. 51, No 2, 2019, pp. 190-198. 
Rodrigues, A.L.O.; Rodrigues, A.; Peroff, D.M. The sky and sustainable tourism development: A case study of a dark sky reserve implementation in Alqueva. International Journal of Tourism Research, Vol. 17, No 3, 2015, pp. 292-302.

Rodrigues, Á.; Filipe, J.A. Sky commons as a basis to explore the touristic potential of the Alqueva area (Portugal). In Rontos, K.; Filipe, J.A.; Tsartas, P. (Eds.). Modeling and new trends in tourism: A contribution to social and economic development. United Kingdom: Nova Science Publishers, 2016, pp. 285-301.

Ruggles, C.; Clotte, M. Heritage Sites of Astronomy and Archeoastronomy in the Context of the UNESCO World Heritage Convention. A Thematic Study. Paris, France: ICOMOS \& International Astronomical Union, 2010.

Snyder, H. Literature review as a research methodology: An overview and guidelines. Journal of Business Research, Vol. 104, 2019, pp. 333-339.

Soleimani, S.; Bruwer, J.; Gross, M.J.; Lee, R. Astro-tourism conceptualisation as special-interest tourism (SIT) field: A phenomonological approach. Current Issues in Tourism, Vol. 22, No 18, 2019, pp. 2299-2314.

UNESCO. Convention concerning the Protection of the World Cultural and Natural Heritage, 1972. Retrieved from https://whc.unesco.org/en/conventiontext/ [accessed 27 January 2020].

UNESCO. Universal Declaration of Human Rights for Future Generations, 1994. Retrieved from http://unesdoc.unesco.org/images/0010/001001/100169Eo.pdf [accessed 25 January 2020].

UNESCO. Convention for the Safeguarding of the Intangible Cultural Heritage 2003, 2003. Retrieved from http://portal.unesco.org/en/ev.phpURL ID=17716\&URL DO=DO TOPIC\&URL SECTION=201.html [accessed 25 January 2020]. 
UNESCO. Proclamation of 2009 as International Year of Astronomy. UNESCO General Conference 33rd Session, 2005. Retrieved from https://whc.unesco.org/en/astronomy/ [accessed 27 January 2020].

Wainscoat, R.J. The magnificent night sky - why it must be protected from light pollution. Proceedings of the International Astronomical Union, Vol. 5, No S260, 2009, pp. 442-448.

Weaver, D. Celestial ecotourism: New horizons in nature-based tourism. Journal of Ecotourism, Vol. 10, No 1, 2011, pp. 38-45.

Wei, Y.; Chen, Z.Q.; Xiu, C.L.; Yu, B.L.; Liu, HX. Siting of Dark Sky Reserves in China Based on Multi-source Spatial Data and Multiple Criteria Evaluation Method. Chinese Geographical Science, Vol. 29, No 6, 2019, pp. 949-961.

Yuna, D.Y.; Premadi, P.W. Considering the Astro-tourism Potential in Indonesia using GCIS-MCDA. Proceedings of the International Astronomical Union, Vol. 14, No A30, 2018, pp. 579.

Article info: Received 16/02/2021. Accepted 25/05/2021. Refereed anonymously. 